\section{Ankara Üniversitesi Eğitim Bilimleri Fakültesi Özel Eğitim Dergisi}

2021, 22(2), 343-367
ARAŞTIRMA

Gönderim Tarihi: 09.02.20

Kabul Tarihi: 14.11.20

Erken Görünüm: 26.11.20

\title{
Otizm Spektrum Bozukluğu Olan Çocuğa Sahip Annelerin Uyguladığı Uyarlanmış Fiziksel Aktivitelerin Annelerin Yaşam Kalitesine Etkisi
}

\author{
Oğuz Kaan Esentürk $\left(D^{1}\right.$
}

\author{
Erkan Yarımkaya ${ }^{(\mathbb{D})_{2}}$
}

$\ddot{O} z$

Giriş: $\mathrm{Bu}$ araştırmada, Otizm Spektrum Bozukluğu (OSB) olan çocuğa sahip anneler tarafından uygulanan uyarlanmış fiziksel aktivite (UFA) programının annelerin yaşam kalitesi üzerindeki etkilerinin incelenmesi amaçlanmıştır.

Yöntem: Karma modelde desenlenen araştırmaya OSB olan çocuğa sahip 24 anne katılmıştır (uygulama grubu = 12 , kontrol grubu $=12$ ). Uygulama grubunda yer alan anneler ve OSB olan çocukları ile birlikte 12 hafta süresince UFA programı yürütülmüştür. UFA programı öncesi, annelerin programda yer alan aktiviteleri uygulama becerisi kazanmaları için üç gün süreyle aile eğitimi oturumları düzenlenmiştir. Araştırmanın nicel verileri Beach Center Aile Yaşam Kalitesi Ölçeği aracılığıyla, nitel verileri ise yarı yapılandırılmış görüşme formu kullanılarak elde edilmiştir.

Bulgular: Bulgular, annelerin yaşam kalitelerinde UFA programı öncesi ve sonrası arasında olumlu yönde anlamlı farklılık olduğunu göstermiştir. Araştırmadan üç hafta sonra elde edilen izleme testinde, UFA programı sonrası annelerin yaşam kalitelerinde gözlenen olumlu yöndeki değişimin devam ettiği belirlenmiştir.

Tartışma: Sonuç olarak, anneler tarafından uygulanan UFA programının araştırmaya katılan annelerin yaşam kaliteleri üzerinde olumlu bir etki oluşturduğu ortaya konulmuştur.

Anahtar sözcükler: Aile katılımı, anne, yaşam kalitesi, otizm spektrum bozukluğu, uyarlanmış fiziksel aktivite.

Atıf için: Esentürk, O. K., \& Yarımkaya, E. (2021). Otizm spektrum bozukluğu olan çocuğa sahip annelerin uyguladığı uyarlanmış fiziksel aktivitelerin annelerin yaşam kalitesine etkisi. Ankara Üniversitesi Ĕgitim $\begin{array}{lllll}\text { Bilimleri Fakültesi Özel Eğitim } & \text { Dergisi, 22(2), } & \text { 343-367. }\end{array}$ https://doi.org/10.21565/ozelegitimdergisi.686849

${ }^{1}$ Dr. Öğr. Üyesi, Erzincan Binali Yıldırım Üniversitesi, esenturk954@gmail.com, https://orcid.org/0000-0002-0566-838X

${ }^{2}$ Sorumlu Yazar: Dr., Milli Eğitim Bakanlığ1, yarimkayaerkan@gmail.com, https://orcid.org/0000-0003-4337-5112 


\section{Giriş}

Erken gelişim evresinde kendini göstererek bireylerin sosyal etkileşim ve iletişim becerilerinde yetersizlik ve tekrarlayıcı davranışlar göstermesine neden olan OSB (Amerikan Psikiyatri Birliği, 2013), bu tanıyı alan çocuğa sahip ailelerin yaşamlarında depresyon, kaygı, eşler arası sorunlar ve stres gibi problemlerin görülmesine yol açmaktadır. Özel gereksinimli çocuğa sahip olan ailelerin yaşamlarında görülme ihtimali yüksek olan bu problemlerin, OSB olan çocuğa sahip ailelerin yaşamlarında daha ciddi bir boyutta olduğu ifade edilmektedir (Hastings \& Brown, 2002; Yirmiya \& Shaked, 2005). OSB olan çocukların ebeveynlerinin, normal gelişim gösteren veya farklı bir özel gereksinim tanısı olan çocukların ebeveynlerine göre daha fazla psikiyatrik bozukluk sergilediği (Yirmiya \& Shaked, 2005), daha fazla stres yaşadığı (Ingersoll \& Hambrick, 2011; Schieve vd., 2007) ve fiziksel aktivite ile sosyal ilişkilerde daha fazla sorunlara maruz kaldığı belirtilmektedir (Mugno vd., 2007; Yirmiya \& Shaked, 2005). OSB olan çocuğa sahip ailelerin yaşadıkları bu zorluklar, onların yaşamlarında birtakım sorunlara yol açmakla birlikte yaşam kalitelerinin de olumsuz yönde etkilenmesine sebep olmaktadır. Diğer bir ifadeyle OSB, sadece bu tanıyı alan kișinin yaşam kalitesi üzerinde değil, aynı zamanda kronik hastalıklarda olduğu gibi ailenin yaşam kalitesi üzerinde de olumsuz bir etkiye sahip olabilmektedir (Farnik vd., 2010; Meltzer, 2001).

OSB olan çocuğa sahip ailelerin yaşam kalitesinin düşük olması; sosyo-ekonomik durum, sosyal destek, ebeveyn-çocuk özellikleri ve başa çıkma stratejileri gibi çeşitli değişkenlerin aile üzerindeki etkileri ile açıklamak mümkündür (Lee vd., 2009; Mugno vd., 2007). Ancak yapılan araştırmalar, OSB tanılı çocuğa sahip olma durumunun aile üyelerinin genel yeterliklerini ve yaşam kalitelerini etkileme potansiyelinin diğer etkenlere göre daha yüksek olduğunu göstermektedir (Schalock, 2000; Shu \& Lung, 2005). Yaşam kalitesi; sağlık ve iyilik durumundan daha geniş ilişkisel, psikolojik ve fiziksel yönler de dahil olmak üzere birçok alanı içinde bulundurmaktadır (Lee vd., 2009).

Aile yaşantısı içinde değerlendirildiğinde bu kavram, ailenin gereksinim duyduğu ihtiyaçları karşılayabilmesi, aile fertlerinin önemli gördükleri şeylere zaman ayırabilmeleri ve bir aile olarak birlikte paylaşımlarda bulunmaktan mutluluk duymaları olarak tanımlanabilir (Hoffman vd., 2006). Dolayısıyla bireylerin yaşam kaliteleri ele alınırken bireysel boyuttan ziyade tüm aile fertlerinin yaşam kalitelerinin birlikte değerlendirilmesi son derece önemli görülmektedir. Bu bağlamda, OSB olan çocuğa sahip ailelerin yaşam kalitesi incelenirken OSB olan çocuğun yanı sıra diğer aile fertlerinin de yaşam kalitesi düzeyi göz önünde bulundurulmalı ve OSB olan çocuğa sahip ailelerin çocukları ile birlikte çeşitli aktivitelere katılımlarını sağlayacak düzenlemeler yapılmalıdır. OSB olan çocukların gelişimi açısından bilimsel dayanağı olan uygulamaları derleyen Ulusal Mesleki Gelişim Merkezi (National Professional Development Center on ASD [NPDC], 2014) ve Ulusal Otizm Merkezi (National Autism Center [NAC], 2015) tarafından önerilen aktivite programlarının ebeveynlerin de sosyal yaşamları üzerinde olumlu etkiler oluşturabileceği, bu nedenle ebeveynlerin yaşam kalitelerinin arttırılması açısından da bu aktivite programlarından faydalanılabileceği belirtilmektedir (Baghdadli vd., 2014; Yarımkaya vd., 2017). Söz konusu kuruluşlar tarafından OSB olan bireylerin gelişimi açısından önerilen uygulamalardan birisi egzersiz ve oyun temelli müdahaleleri içinde barındıran Uyarlanmış Fiziksel Aktivitedir (UFA).

UFA, NPDC on ASD (2014) raporunda bilimsel dayanaklı uygulamalar içerisinde yer almakta, NAC (2015) raporunda ise umut vaat eden uygulamalar arasında bulunmaktadır. UFA kavramı, özel gereksinimli bireylerin fiziksel aktiviteleri için kullanılmaktadır (Özer, 2010). UFA, özel gereksinimli tüm bireylerin fiziksel aktivite hedefini başarabilmesi için profesyoneller aracılığıyla sunulan fiziksel aktiviteler, beden eğitimi aktiviteleri, egzersiz faaliyetleri ve oyun aktivitelerini kapsamaktadır (Sherrill, 2004). UFA, fiziksel aktivite uygulamalarına katılımda sorunlar yaşayan özel gereksinimli bireylere yönelik hazırlanan eğitim programlarında, bu bireylerin gelişim özellikleri doğrultusunda birtakım uyarlamalar yapılmasına olanak tanımaktadır (Block, 2007; Schultheis vd., 2000). Özel gereksinimli bireylerin ihtiyaçları doğrultusunda şekillendirilen UFA programları sayesinde, aralarında OSB olan bireylerin de bulunduğu özel gereksinimli bireylerin fiziksel aktivitelere etkin bir şekilde katılımı sağlanmakta ve onların çok yönlü gelişimlerine katkı sunulmaktadır (Petrus vd., 2008; Sowa \& Meulenbroek, 2012; Srinivasan vd., 2014).

Alanyazında, OSB ve UFA üzerine yürütülen çok sayıda çalışmaya rastlamak mümkündür. Söz konusu çalışmalarda, UFA programlarına katılımın OSB olan bireylerin duyuşsal özelliklerini (Bass vd., 2009), bilişsel gelişimlerini (Nicholson vd., 2011), motor becerilerini (Pan, 2010) ve dil gelişimlerini (Yarımkaya vd., 2017) desteklediği ve stereotipik davranışların azalmasına (Prupas \& Reid, 2001) katkı sunduğu ortaya konulmaktadır. Bununla birlikte, OSB olan bireylerin gelişim alanları üzerinde aile katılımlı UFA programlarının etkileri konusunda inceleme yapan çalışmalara da alanyazında rastlamak mümkündür. Örneğin; Esentürk (2019) aile 
katılımlı UFA programının OSB olan çocukların iletişim becerileri üzerinde etkili olup olmadığını incelediği çalışmasında, annelerin OSB olan çocuklarıyla birlikte gerçekleştirdiği UFA programı sonrası OSB olan çocukların iletişim becerilerinde olumlu yönde gelişmeler olduğu sonucunu ortaya koymuştur. Solomon ve diğerleri (2014) ise anneler tarafından uygulanan UFA programının OSB olan çocukların iletişim becerileri üzerindeki etkilerini ele aldığı çalışmasında, anneler tarafından uygulana UFA programının OSB olan çocukların iletişim becerilerine olumlu katkılar sağladığını tespit etmiştir. Alanyazında görüldüğü üzere, OSB ve UFA üzerine araştırma yapan çalışmalar arasında yalnızca iki çalışmanın (Esentürk, 2019; Solomon vd., 2014) OSB olan bireylerin beden eğitimi sürecinde aile katılımına yer verdiği anlaşılmaktadır. Oysaki özel eğitimin önemli bir ilkesi, ailelerin özel gereksinimi olan çocuklarının eğitim sürecinin her aşamasında etkin bir rol almasını içermektedir. Özel gereksinimli çocuklara sunulan eğitim uygulamalarında ailenin aktif katılımı sağlanmazsa hem çocuk hem de aile açısından aktivitelerin belirlenen amaçlara ulaşamayacağı belirtilmektedir (Diken, 2009; Sameroff \& Fiese, 2000). Dolayısıyla, özel gereksinimli çocuklara yönelik eğitim programlarına aile katılımının sağlanmasının çok önemli bir unsur olduğu anlaşılmaktadır (Osterling \& Dawson, 1997; Hurth vd., 1999). Nitekim farklı disiplinlerde yürütülen çalışmalara bakıldığında, OSB olan bireylerin eğitimi sürecinde aile katılımına yer veren birçok çalışmaya rastlamak mümkündür (Acar vd., 2017; Baker \& McCurry, 1984; Baker \& Brihtman, 1984; Bergan vd., 1983; Olçay-Gül \& Tekin-İftar, 2016; Rosenberg vd., 1986). Beden eğitimi alanında ise UFA ve aile katılımı üzerine yapılan çalışmaların genellikle zihinsel yetersizliği olan bireyler üzerine gerçekleştirildiği görülmektedir (Demirdağ, 2010; İlhan, 2010; Sukan, 2013). Aile katılımı içersin ya da içermesin OSB ve UFA üzerine inceleme yapan alanyazındaki çalışmaların yalnızca OSB olan bireylerin gelişim özelliklerine yönelik sonuçlar sunduğu, ebeveynlere ilişkin herhangi bir bilgi ortaya koymadığı belirlenmiştir. Mevcut araştırmada, alanyazında yer alan bu boşluk göz önünde bulundurularak OSB olan çocuğa sahip anneler tarafından sunulan UFA programının annelerin yaşam kaliteleri üzerindeki etkileri üzerinde durulmuştur. Çalışmanın alanyazına katkı sağlamasının yanı sıra içerdiği örnek aktiviteler ve aile eğitim programı bakımından ebeveynlere ve uzmanlara UFA programının aileler tarafından uygulanması konusunda rehber olacağı düşünülmektedir. OSB'nin yalnızca bu tanıyı alan bireyler üzerinde değil aynı zamanda OSB olan çocuğa sahip ailelerin yaşamları üzerindeki etkileri göz önünde bulundurulduğunda, UFA programına çocuklarıyla birlikte katılan annelerin yaşam kalitelerindeki değişimleri incelemeyi amaç edinen bu çalışmanın önemi daha iyi anlaşılacaktır. Bu bilgiler ışında mevcut araştırmanın amacı, anneler tarafından uygulanan UFA programının OSB olan çocuğa sahip annelerin yaşam kaliteleri üzerinde etkisinin olup olmadığının incelenmesidir. Bu amaçla aşağıdaki sorulara yanıt aranmıştır:

1. Uygulama ve kontrol gruplarındaki annelerin yaşam kalitesi bakımından ön test puanlarına göre düzeltilmiş son test puanları arasında anlamlı bir farklılık var mıdır?

2. Uygulama grubundaki annelerin yaşam kalitesi bakımından ön test, son test ve izleme testi puanları arasında anlamlı bir farklılık var midır?

3. Uygulama grubundaki annelerin UFA programı sonrası yaşam kalitelerindeki değiş̧ime yönelik görüşleri nasildır?

\section{Yöntem}

\section{Araştırmanın Modeli}

Anne-çocuk uygulamalarına dayalı UFA programının annelerin yaşam kalitesi düzeyine etkisinin incelendiği bu araştırma, nicel ve nitel veri toplama yöntem ve tekniklerinin birlikte ele alındığı karma modelde tasarlanmıştır. Creswell'e (2005) göre, karma yöntemde veriler aynı zamanda ya da ardışı bir şekilde toplanıp analiz edilmekte ve elde edilen bulgular bütüncül bir yaklaşımla değerlendirilmektedir. Bu araştırmada, nicel veri ile ölçülen özelliğe ilişkin durumun nitel veri ile gerekçelendirilmesine olanak sağlaması nedeniyle karma araştırma modellerinden sıralı açımlayıcı desen tercih edilmiştir. Sıralı açımlayıcı desende önce nicel veriler toplanmakta ardından nicel verilerin açıklanması ve derinlemesine bir biçimde incelenmesi amacıyla nitel veriler elde edilmektedir (Creswell \& Plano-Clark, 2014).

Araştırmanın ilk aşaması olan nicel bölümde anneler tarafından uygulanan UFA programının annelerin yaşam kalitesi düzeyine etkisini ortaya koymak için ön test-son test kontrol gruplu deneysel modelden yararlanılmıştır. Bilimsel değeri en yüksek araştırma modellerinden biri olarak kabul edilen bu modelde uygulama ve kontrol grubu olmak üzere iki grup oluşturulmaktadır (Karasar, 2015). Bu gruplardan birisine (uygulama grubu) araştırmada etkisi incelenen eğitim programı uygulanmakta ve ölçülmek istenen özelliğe ait araştırma öncesi ve sonrası elde edilen puanlar arasında farklılık olması durumunda, bunun eğitim programı kaynaklı olduğu kabul edilmektedir (Ekici, 2008). 
Araştırmanın ikinci aşaması olan nitel bölümde ise uygulama grubunda yer alan anneler ile UFA programının uygulanmasının ardından yarı yapılandırılmış görüşmeler gerçekleştirilmiştir. Görüşmelerde UFA programı sonrası annelerin yaşam kalitesi düzeyindeki olası değişikliklerin detaylı şekilde incelenmesi amaçlanmıştır. Yarı yapılandırılmış görüşme, bir konu hakkında katılımcıların özgürce düşüncelerini belirtmelerine imkân sunmaktadır (Bogdan \& Biklen, 2007).

\section{Çalışma Grubu}

Araştırmaya, OSB tanısı olan çocuğa sahip toplam 24 anne gönüllülük esasına göre dâhil edilmiştir. Annelerden, kendileri ve OSB olan çocuklarının araştırmaya katılımı konusunda izinleri yazılı olarak alınmıştır. Çalışma grubunda yer alan anneler ve onların OSB olan çocuklarına ilişkin tanımlayıcı bilgiler Tablo 1'de sunulmuştur.

Tablo 1

Katılımcılara İlişkin Tanımlayıcı Bilgiler

\begin{tabular}{|c|c|c|c|c|c|c|c|c|c|c|c|c|}
\hline \multicolumn{7}{|c|}{ Uygulama grubu } & \multicolumn{6}{|c|}{ Kontrol grubu } \\
\hline \multirow{2}{*}{ Sira } & \multicolumn{3}{|c|}{ Anne } & \multicolumn{3}{|c|}{ Çocuk } & \multicolumn{3}{|c|}{ Anne } & \multicolumn{3}{|c|}{ Çocuk } \\
\hline & Yaş & Eğgitim $^{\mathrm{a}}$ & Gelir & Cinsiyet & Yaş & Tan1 & Yaş & Eğitim & Gelir & Cinsiyet & Yaş & Tanı \\
\hline 1. & 54 & Üni. & Orta & Erkek & 14 & OSB & 49 & Lise & Orta & Erkek & 12 & OSB \\
\hline 2. & 48 & İlkokul & Orta & K1z & 16 & OSB & 48 & Lise & Orta & Erkek & 11 & OSB \\
\hline 3. & 51 & Lise & Orta & $\mathrm{K}_{1 \mathrm{z}}$ & 15 & OSB & 57 & Lise & Orta & Erkek & 14 & OSB \\
\hline 4. & 39 & Üni. & Orta & Erkek & 12 & OSB & 36 & İlkokul & Orta & $\mathrm{K} 1 \mathrm{Z}$ & 9 & OSB \\
\hline 5 & 36 & Lise & Orta & Erkek & 11 & OSB & 43 & Lise & Orta & Erkek & 10 & OSB \\
\hline 6 & 37 & Lise & Orta & $\mathrm{K}_{1 \mathrm{Z}}$ & 11 & OSB & 42 & Lise & Orta & Erkek & 10 & OSB \\
\hline 7. & 35 & Lise & Orta & Erkek & 10 & OSB & 56 & Üni. & Orta & K1z & 13 & OSB \\
\hline 8. & 37 & İlkokul & Orta & Erkek & 12 & OSB & 39 & İlkokul & Orta & $\mathrm{K}_{1 \mathrm{Z}}$ & 11 & OSB \\
\hline 9. & 41 & Lise & Orta & Erkek & 11 & OSB & 41 & Lise & Orta & $\mathrm{K}_{1 \mathrm{Z}}$ & 11 & OSB \\
\hline 10. & 43 & Üni. & Orta & $\mathrm{K}_{1 \mathrm{Z}}$ & 9 & OSB & 45 & Lise & Orta & $\mathrm{K}_{1 \mathrm{Z}}$ & 12 & OSB \\
\hline 11. & 48 & Lise & Orta & Erkek & 12 & OSB & 42 & İlkokul & Orta & Erkek & 11 & OSB \\
\hline 12. & 45 & Lise & Orta & $\mathrm{K}_{1 \mathrm{Z}}$ & 10 & OSB & 48 & Üni. & Orta & $\mathrm{K} 1 \mathrm{Z}$ & 14 & OSB \\
\hline
\end{tabular}

${ }^{\mathrm{a} O S B}$ : Otizm Spektrum Bozukluğu; Üni: Üniversite.

Tablo 1 incelendiğinde, çalışmada uygulama ve kontrol grubu olmak üzere iki grup yer almaktadır. Uygulama grubunda yer alan annelerin orta gelir düzeyinde yer aldığı, yaşlarının 35 ile 54 arasında değiştiği ve çoğunluğunun lise mezunu olduğu anlaşılmaktadır. Uygulama grubunda yer alan annelerin çocuklarının OSB tanısı aldığı ve yaşlarının 9 ile 16 arası değiştiği görülmektedir. Kontrol grubunda yer alan annelerin ise orta gelir düzeyinde yer aldığı, yaşlarının 36 ile 57 arasında değiştiği ve çoğunluğunun lise mezunu olduğu anlaşılmaktadır. Uygulama grubunda yer alan annelerin çocuklarının OSB tanısı aldığı ve yaşlarının 9 ile 14 arası değiştiği görülmektedir. Çalışmada, uygulama ve kontrol gruplarının belirlenmesi sürecinde anneler, seçkisiz atama ile 12'şer kişilik iki gruba ayrılmış ve annelere Beach Center Aile Yaşam Kalitesi Ölçeği uygulanarak, bağımlı değişken açısından birbirine denk grupların oluşturulması hedeflenmiştir. Grupların yaşam kalitesi ölçeğinden aldıkları puanlar arasında fark olup olmadığı bağımsız gruplar t testi ile incelenmiştir. Analiz sonucu, gruplarda yer alan annelerin yaşam kalitesi düzeyinin farklılık göstermediğini ortaya koymaktadır $\left(t_{(22)}=0.89 ; p>.05\right)$. Araştırma sürecinde uygulamalara dahil edilmeyen ve yalnızca ölçümlerde yer alan kontrol grubundaki anneler ile araştırmanın sonlandırılmasının ardından uygulama sürecindeki tüm aşamalar gerçekleştirilmişstir.

\section{UFA Programının Uygulanması}

Araştırmanın bağımsız değişkeni anneler tarafından çocuklarına uygulanan UFA programıdır. UFA programının teorik çerçevesinin hazırlanması sürecinde, Greenspan ve meslektaşlarının gelişimsel, bireyselleştirilmiş ve ilişki odaklı (Developmental, Individual Difference, Relationship-based [DIR]) modelinden yararlanılmıştır (Greenspan, 1992). Ayrıca, ilgili alanyazın (Fragala-Pinkham vd., 2005; Garcia-Villamisar \& Dattilo, 2010; Gutman vd., 2012; Kunzi, 2015; Menear \& Neumeier, 2015; Srinivasan vd., 2014; Staples vd., 2011; Todd \& Reid, 2006) incelenerek, aktivitelerde yer alan becerilerin anne-çocuk arasındaki etkileşimi ve geçirdikleri zamanın kalitesini en üst noktaya taşıması, kazanma-kaybetme ikilemlerini içermesi ve sözel ve sözel olmayan şekilde katılımcı çocukları iletişim kurmaya teşvik etmesine dikkat edilmiştir. Programda; 1sınma aktiviteleri, eğitsel oyunlar, istasyon parkurları, sportif yarışmalar, işlevsel hareketler ve esnetme-soğuma çalışmaları yer almıştır. Program 12 hafta boyunca haftada üç gün 40’ar dk süreyle uygulanmıştır. Annelerin çocukları ile birlikte uyguladıkları UFA programı, uygulama öncesinde yapılması gereken hazırlıklar ve uygulama 
sürecinde izlenmesi gereken basamaklar olmak üzere iki bölümden oluşmaktadır. Aile eğitimleri ile UFA programını oluşturan bu iki bölümün öğretimi amaçlanmıştır (bk. Tablo 2).

\section{Tablo 2}

UFA Programının Hazırlık ve Uygulama Sürecinde İzlenmesi Gereken Basamaklar

\begin{tabular}{|c|c|}
\hline Hazırlık aşaması & Uygulama süreci \\
\hline 1. Aktiviteyi planlar & 1. Aktivite alanını gözden geçirir \\
\hline 1.1. Uygun çalışma zamanlarını belirler & 2. Çocuğun dikkatini aktiviteye yöneltir \\
\hline $\begin{array}{l}\text { 1.2. Aktivitenin adı, amacı, süresi, yeri ve materyalleri } \\
\text { yazar }\end{array}$ & 3. Isınma Hareketlerini Yapar \\
\hline $\begin{array}{l}\text { 1.3. Aktivitede kullanılacak ödülleri her kategoride } \\
\text { olacak şekilde yazar }\end{array}$ & 4. Aktivite kurallarını açıklar \\
\hline $\begin{array}{l}\text { 1.4.Uyguladiğ aktiviteye, çocuğuna ve kendisine } \\
\text { ilişkin değerlendirmelerini yazar }\end{array}$ & 5. Uygun iletişim becerilerini kullanır \\
\hline $\begin{array}{l}\text { 2. Çocuğun dikkatini dağıtabilecek uyaranları ortamdan } \\
\text { uzaklaştırır }\end{array}$ & 6. Hedef uyaranı (yönerge) sunar \\
\hline 3. Aktivitede kullanılacak olan ödülleri hazırlar & 7. Çocuğun hedef davranışlarına uygun tepki verir \\
\hline 4. Materyalleri kontrol eder & $\begin{array}{l}\text { 8. Çocuğun aktivitelerden sıkılması durumunda gerekli } \\
\text { tedbirleri alır }\end{array}$ \\
\hline 5. Aktivite alanının hazırlanmasında çocuğa görev ve & 9. Esneme-soğuma çalışmalarını yapar \\
\hline sorumluluk verir & 10. Çocuğu bir sonraki aktiviteye motive eder \\
\hline
\end{tabular}

\section{Aile (Anne) Eğitim Programı}

Annelerin çocuklarına UFA programını uygulamakta yeterli hale gelmeleri için aile eğitim programı uygulanmıştır. $\mathrm{Bu}$ program çerçevesinde annelere UFA programının uygulama öncesinde yapılması gereken hazırlıklar ve uygulama sürecinde izlenmesi gereken basamakların öğretimi amaçlanmıştır. Aile eğitimi ile ilgili yapılan araştırmalar (Lequia vd., 2013; Mazurik-Charles \& Stefanou, 2010), ailelere yönelik eğitim programlarının bilgilendirici eğitim sunumları, model olma, rol oynama ve geri bildirim sunma uygulamalarıyla gerçekleştirildiği görülmüştür. İlgili alanyazın ve araştırmanın uygulama boyutu göz önüne alınarak aile eğitim programı kapsamında, bilgilendirici eğitim sunumları, UFA programı uygulama öncesi hazırlıklara model olma, UFA programı uygulama öncesi hazırlıkları deneme, UFA programı uygulama çalışmalarına model olma ve UFA programı uygulama çalışmaları yer almaktadır. Şekil 1'de annelerin eğitim sürecine yönelik görsel yol haritası sunulmuştur. İfade edilen aşamaların birinden diğerine annelerin geçebilmesi için Tablo 2'de yer alan basamakların \%100 oranında kazanılmış olması gerekmektedir. Araştırmada UFA programının anneler tarafından güvenilir olarak uygulanıp uygulanmadığının belirlenmesi amacıyla ayrıca veri toplanmamıştır. Bu sınırlılığın nedeni araştırmadaki katılımcı sayısının fazla olmasıdır. Bu durum araştırmanın bir sınırlılığı olarak düşünülmektedir. Ancak uygulamalar boyunca anneler araştırmacılar tarafından sürekli gözlenmiş ve anında dönütler verilerek eğitimlerde kazanımların dışına çıkılmaması sağlanmıştır.

\section{Şekil 1.}

Aile Ĕ̌itim Programı Uygulama Süreci

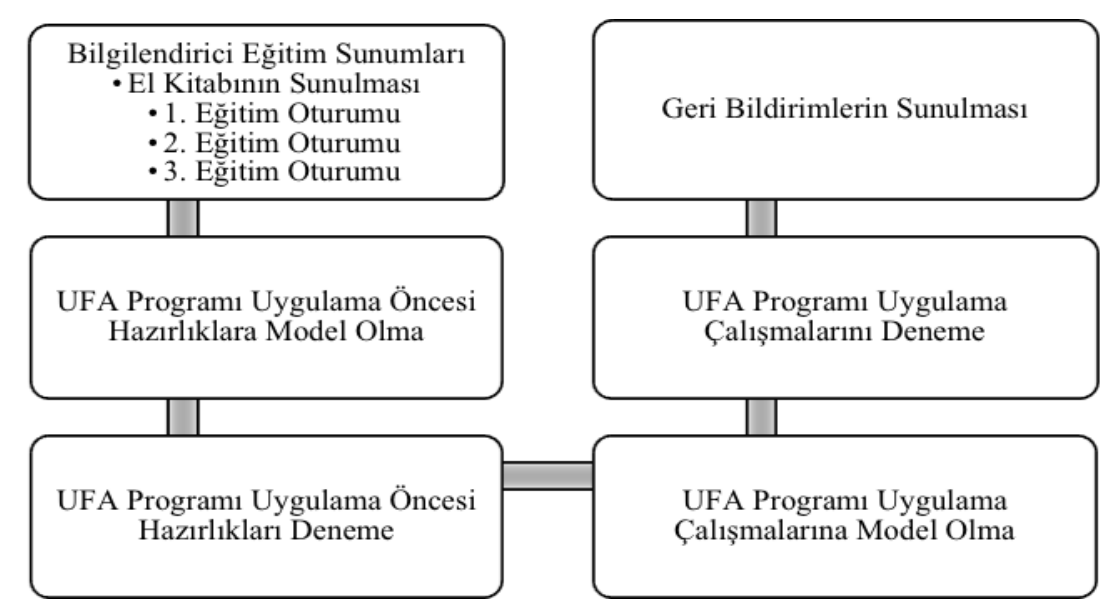




\section{Bilgilendirici Eğitim Sunumlart}

Bilgilendirici eğitim sunumları, annelere aile eğitim programı kapsamında olușturulan içeriklerin teorik olarak sunulduğu bölümdür. Bu sunumların gerçekleştirilmesinde, araştırmacı tarafından tasarlanan el kitabının içeriği temel alınmıştır. Ailelerin bilgilendirilmeleri aşamasında, ailelere basılı notlar sunmak, el kitabı, video klip ya da CD gibi materyaller hazırlayıp sunmak eğitimlerin yararı açısından önemlidir (Lequia vd., 2013). El kitabının hazırlanması sürecinde ilgili alanyazında (Olçay-Gül, 2016) yer alan aile eğitim programları kapsamındaki bilgilendirici el kitaplarından yararlanılarak, mevcut çalışmanın amaçları doğrultusunda gerekli uyarlamalara gidilmiştir. Ayrıca bu süreçte anlaşı1ır bir dil kullanımına dikkat edilerek, teknik terimlerin kullanımından kaçınılmıştır. Annelerin eğitiminin teorik boyutunda kullanılan el kitabı üç bölümden oluşmuştur. Birinci bölümde, OSB olan bireylerin genel gelişim özellikleri, UFA programının ne olduğu, UFA programı kapsamındaki aktivitelerin uygulanması sürecinde çocuklara nasıl yaklaşılması gerektiğine dair bilgiler yer almaktadır. İkinci bölümde, UFA programının uygulama öncesinde yapılması gereken hazırlıklara yönelik bilgiler ve örnek uygulama öncesi hazırlık slâytları yer almaktadır. Üçüncü bölümde ise, UFA programı uygulama sürecinde izlenmesi gereken basamaklar ve örnek uygulama slâyt ve videoları yer almaktadır. Annelere el kitabının üç bölümden oluşan içeriği, üç eğitim oturumunda sunulmuştur. Tablo 3’te el kitabının sunum planı verilmiştir.

Tablo 3

El Kitabı Sunum Planı

\begin{tabular}{|c|c|c|}
\hline 1. Bölüm: Ön bilgiler & $\begin{array}{l}\text { 2. Bölüm: UFA programı uygulama } \\
\text { öncesi hazırlık basamakları }\end{array}$ & $\begin{array}{c}\text { 3. Bölüm: UFA programı uygulama } \\
\text { sürecinde izlenmesi gereken } \\
\text { basamaklar }\end{array}$ \\
\hline $\begin{array}{l}\text { Oturum: OSB olan bireylerin genel } \\
\text { gelişim özellikleri, UFA programının } \\
\text { ne olduğu, UFA programı } \\
\text { kapsamındaki aktivitelerin } \\
\text { uygulanması sürecinde çocuklara nasıl } \\
\text { yaklaşılması gerektiği çocuklarına } \\
\text { nasıl yaklaşım sergileyeceğini bilir. } \\
\text { Kazanımlar: } \\
\text { 1. Anneler, OSB olan çocukların genel } \\
\text { gelişim özelliklerini bilir. } \\
\text { 2. Anneler, UFA programı kavramını } \\
\text { tanımlar. } \\
\text { 3. Anneler, UFA programı } \\
\text { kapsamındaki aktiviteler süresince } \\
\text { çocuklara nasıl yaklaşacağını bilir. } \\
\text { Süre: 50dk } \\
\text { Materyal: El kitabı, kâğıt, kalem ve } \\
\text { silgi } \\
\text { Öğretim/Sunu Yöntemi: Power Point } \\
\text { Tamamlanacak Aktivite/Ödev: } \\
\text { Değerlendirme soruları }\end{array}$ & $\begin{array}{l}\text { Oturum: UFA programının } \\
\text { uygulama öncesinde yapılması } \\
\text { geren hazırlılara yönelik bilgiler } \\
\text { ve örnek uygulama öncesi hazırlık. } \\
\text { Kazanım: Anneler, UFA } \\
\text { programının uygulama öncesi } \\
\text { hazırlıklarının nasıl yapılması } \\
\text { gerektiğini bilir. } \\
\text { Süre: 50dk } \\
\text { Materyal: UFA programı el kitabı, } \\
\text { slâytlar, kalem, kâğıt ve silgi } \\
\text { Öğretim/Sunu Yöntemi: Power Point } \\
\text { Tamamlanacak Aktivite/Ödev: } \\
\text { Değerlendirme soruları }\end{array}$ & $\begin{array}{l}\text { Oturum: UFA programının uygulama } \\
\text { sürecinde izlenmesi gereken } \\
\text { basamakların neler olduğu ve örnek } \\
\text { uygulama slâytlarının sunulması } \\
\text { Kazanım: Anneler, UFA programı } \\
\text { uygulamasının nasıl yapılması } \\
\text { gerektiğini bilir. } \\
\text { Süre: 50dk } \\
\text { Materyal: UFA programı el kitabı, } \\
\text { slâytlar, kalem, kağıt ve silgi } \\
\text { Öğretim/Sunu Yöntemi: Power Point } \\
\text { Tamamlanacak Aktivite/Ödev: } \\
\text { Değerlendirme soruları }\end{array}$ \\
\hline
\end{tabular}

\section{Uygulama Öncesi Hazırlıklara Model Olma}

Aile eğitimlerinin teorik boyutunun tamamlanmasının ardından uygulamalı eğitimlere geçilmiştir. Bu aşamada araştırmacı, öncelikle annelere UFA programının uygulama öncesi hazırlıklarının yapılmasında dikkat edilmesi gereken basamakları açıklamıştır (bk. Tablo 3). Ardından uygulama öncesi hazırlıkların yapılmasına yönelik olarak örnek bir aktivite üzerinden araştırmacı, kendisinin anne, annenin de çocuk olduğu rol oynama çalışmalarına yer vermiştir.

\section{Uygulama Öncesi Hazırlıkları Deneme}

$\mathrm{Bu}$ aşamada annelerin UFA programının uygulama öncesi hazırlıklarını denemesi istenmiştir. Bu kapsamda model olma aşamasında kullanılan örnek aktivite üzerinden annelerin araştırmacı, araştırmacının da çocuk olduğu rol oynama çalışmaları gerçekleştirilmiştir. 


\section{Uygulama Çalışmalarına Model Olma}

$\mathrm{Bu}$ aşamada araştırmacı, UFA programının uygulanmasında izlenilmesi gereken basamakları açıklayarak (bk. Tablo 3), uygulama çalışmalarına yönelik model olmuştur. Uygulama çalışmalarına model olma aşamasında araştırmacı, kendisinin anne, annelerin de çocuk olduğu rol oynama çalışmalarına yer vermiştir.

\section{Uygulama Çalışmalarını Deneme}

$\mathrm{Bu}$ aşamada annelerden, önceden hazırlığı yapılmış bir ortamda uygulama çalışması yapması istenmiştir. $\mathrm{Bu}$ kapsamda annelerin uygulamacı, uygulamacının da çocuk olduğu rol oyun çalışmaları gerçekleştirilmiştir. Ailelerin yetiştirilme sürecine yönelik uygulamalı eğitimler (model olma ve deneme çalışmaları) annelerin teorik olarak edindikleri bilgileri uygulamalı olarak gerçekleştirebilecekleri firsatlar yaratmıştır. Aile eğitiminin teorik ve uygulamalı aşamaları sonunda anne-çocuk uygulamalarına geçilerek uygulama sürecine başlanılmıştır.

\section{Ortam ve Araç-Gereçler}

Uygulama sürecine başlanmadan önce annelere yönelik eğitim faaliyetleri gerçekleştirilmiştir. Aile eğitimleri, uygulamacının kurumu bünyesinde yer alan bir derslikte yapılmıştır. Derslik, annelerin rahat edebileceği oturma düzenine, sunumlar için gerekli projeksiyon aracına, beyaz yazı tahtasına ve ayarlanabilir ısı ve ışık düzenine sahiptir. Aile eğitimlerinde her bir anneye uygulamaları gerçekleştirebilmesi için gerekli teorik bilgilerin yer aldığı el kitabı verilmiştir.

Aile eğitimlerinin uygulama kısımları ve UFA programı kapsamındaki aktiviteler araştırmacının kurumu bünyesinde yer alan spor salonunda gerçekleştirilmiştir. Spor salonu yaklaşık $200 \mathrm{~m}^{2}$ dir. Spor salonu kauçuk bir zemine sahip olup, duvarları yumuşak minderler ile kaplıdır. Spor salonunda ödüllerin ve kullanılacak materyallerin katılımcı çocuğun göremeyeceği şekilde muhafaza edilmesine imkân sağlayacak bir alan bulunmaktadır.

\section{Veri Toplama Araçları}

\section{Beach Center Aile Yaşam Kalitesi Ölçeği}

Araştırma kapsamında annelerin yaşam kalitesi düzeyine ilişkin veriler, Beach Center Aile Yaşam Kalitesi Ölçeği (BCAYKÖ) kullanılarak elde edilmiştir. BCAYKÖ’nün Türkçe geçerlik ve güvenirlik çalışması Meral (2011) tarafından yapılmıştır. BCAYKÖ, özel gereksinimi olan çocukları bulunan ailelerin yaşam kalitesi düzeyinin tespiti amacıyla kullanılan ve beşli derecelendirme tarzındaki 25 sorudan oluşan bir ölçme aracıdır. Yanıtlayanlar her maddeye 1 ile 5 arasında değer verebilmektedir. 5'li Likert tipi ölçek olarak düzenlenen veri toplama aracında maddeler, "Kesinlikle Katılıyorum (5 puan), Katılıyorum (4 puan), Kararsızım (3 puan), Katılmıyorum (2) Kesinlikle Katılmıyorum (1 puan)" olarak derecelendirilmiş̧ir. BCAYKÖ aracılığıyla ailelerin yaşam kalitesi düzeyi; ebeveynlik, aile etkileşimi, duygusal yeterlik, yetersizliğe ilişkin destek ve finansal/fiziksel/materyal yeterliği olmak üzere 5 alt boyutta ölçülebilmektedir. Ölçekten en düşük 25 puan, en yüksek ise 125 puan alınabilmektedir. Ölçekte yer alan tüm maddeler olumlu olduğu için ölçekten alınan puanlar arttıkça yaşam kalitesi düzeyinin de arttığı kabul edilmektedir. Ölçeğin geçerliği ve güvenirliği kapsamında; Doğrulayıcı Faktör Analizi (DFA), ölçüt bağıntılı geçerlik, Cronbach's alpha $(\alpha)$ iç tutarlılık katsayısı, iki-yarı güvenirlik, madde-toplam korelasyonu ve $\% 27$ alt-üst grupların madde ortalamaları arasındaki farkların anlamlılığı değerlendirilmiştir (Meral \& Cavkaytar, 2013). DFA sonucu elde edilen model, BCAYKÖ’nün 5 alt boyutlu yapısıyla kabul edilebilir bir uyum iyiliğine sahip olduğunu ortaya koymuştur. BCAYKÖ'nün ölçüt bağıntılı geçerliğinin incelenmesi amacıyla Çok Boyutlu Algılanan Sosyal Destek Ölçeği'nden faydalanılmıştır. Ölçeklerin genel toplam ve alt boyut puanları arasında pozitif ve anlamlı bir ilişki olduğu dolayısıyla BCAYKÖ'nün ölçüt bağıntılı geçerliği sağladığı belirlenmiştir. Güvenirlik çalışmaları kapsamında, hesaplanan Cronbach's alpha değerleri genel aile yaşam kalitesi ve 5 alt boyutta .80 ile .94 arasında değişmektedir (Meral \& Cavkaytar, 2013). Mevcut araştırma kapsamında ölçeğin geneline ilişkin hesaplanan Cronbach's alpha değeri ise .85 olarak belirlenmiş̧tir.

\section{Yarı Yapılandırılmış Görüşme Protokolü}

Yaşam kalitesi görüşme protokolünün hazırlanmasında ilk olarak ilgili alanyazından yararlanılarak teorik çerçeve oluşturulmuştur. Bu doğrultuda görüşme sorularının hazırlanmasında BCAYKÖ'de yer alan maddelerden yararlanılmıştır. Protokolde yer alacak görüşme sorularının araştırmanın amacına bağlı kalmasına dikkat edilerek, aile etkileşimi boyutuna yönelik 3 soru, duygusal yeterlik boyutuna yönelik 3 soru, ebeveynlik boyutuna yönelik 3 soru, finansal/fiziksel/materyal yeterliği boyutuna yönelik 3 soru ve yetersizliğe ilişkin destek boyutuna yönelik 
3 soru olmak üzere toplam 15 soru oluşturulmuştur. Görüşme sorularının hazırlanmasında Türkçe, çocuk gelişimi ve beden eğitimi alanında uzman akademisyenlerin görüş ve önerileri dikkate alınmıştır. Akademisyenlerin görüş ve önerileri neticesinde şekillendirilen görüşme protokolü, araştırmaya katılmayan OSB olan çocuğa sahip 2 anne ile yapılan görüşmelerde anlaşılırlık bakımından sınanmış ve son şeklini almıştır. Görüşme protokolü uygulanmadan önce, çalışma grubunda yer alan annelere araştırma hakkında bilgi verilmiş ve araştırma sonucu ulaşılacak sonuçların nasıl değerlendirileceğine ilişkin açıklama yapılmıştır. Görüş̧melerde ses kayıt cihazının kullanımı için annelerin izinleri alınmıştır. Görüş̧meler her bir anneyle yaklaşık 7-14 dk arası sürmüştür.

\section{Verilerin Toplanması}

Araştırmada ilk olarak, OSB olan çocuğa sahip annelerin çalışma öncesi yaşam kalitesi düzeyinin belirlenmesi amacıyla çalışmadan bir hafta önce annelere BCAYKÖ ön test olarak uygulanmıştır. İkinci olarak, annelerin UFA programını uygulamakta yeterli hale gelmeleri için UFA programı öncesi üç gün süreyle aile eğitim programı düzenlenmiştir. Üçüncü olarak, uygulama grubunda yer alan anneler ve onların OSB olan çocukları ile birlikte 12 hafta süresince UFA programı yürütülmüştür. Dördüncü olarak, UFA programının tamamlanmasından bir hafta sonra annelerin yaşam kalitesi düzeyinin belirlenmesi amacıyla BCAYKÖ annelere son test olarak uygulanmıştır. Son olarak, annelerin yaşam kalitesi düzeyindeki olası değişimin araştırma tamamlandıktan sonra devam edip etmediğini belirlemek amacıyla, araştırmadan üç hafta sonra BCAYKÖ aracıllığılla annelerin yaşam kalitesine ilişkin izleme verisi toplanmıştır.

\section{Verilerin Analizi}

Araştırmanın ilk aşamasında elde edilen nicel verilerin analizi sürecinde istatistik paket programından faydalanılmıştır. Nicel verilerin analizinde öncelikle çalışma grubundan toplanan verilerin dağılım özellikleri ortaya konularak, kullanılacak istatistikî yöntemlere karar verilmiştir. Verilerin normal dağılıma uygun olup olmadığı Kolmogorov-Smirnov testi ve basıklık-çarpıklık değerlerine göre belirlenmiştir. Ardından frekans, yüzde, ortalama ve standart sapma gibi betimsel istatistikler hesaplanmış ve grupların ön test yaşam kalitesi puanları arasında anlamlı farklılık olup olmadığının belirlenmesinde bağımsız gruplar $t$ testi kullanılmıştır. Grupların ön-test sonuçlarına göre düzeltilmiş son-test puan ortalamaları arasındaki farkın anlamlılığını sınamak için kovaryans analizi tekniğine başvurulmuştur (Büyüköztürk, 2007). Ayrıca uygulama grubundaki annelerin ön test, son test ve izleme testi arasında herhangi bir anlamlı farklılık olup olmadığını belirlemek amacıyla tekrarlayan ölçümler için ANOVA testi kullanılmıştır.

Araştırmanın ikinci aşamasında elde edilen nitel verilerin analizinde ise tematik analiz tekniğine başvurulmuştur. Liamputtong' e (2009) göre tematik analiz, analize ilişkin tematik bir çerçeve oluşturulması ve bu çerçevenin ışığında verilerin tanımlanması, tanımlanan verilere bağlı olarak bulgular arasındaki neden-sonuç ilişkisinin araştırılması ve araştırmacı tarafından gözlemlenen ilişkilerin yorumlanması sürecidir. Tematik analiz tümevarım ve tümdengelim olmak üzere iki şekilde uygulanabilmektedir. Bu araştırmada tümevarımcı tematik analiz yöntemi kullanılmıştır. Tümevarımcı tematik analizde, tanımlanmış tema ve kategorilerin verilerle güçlü bir iliş̧ki içinde olmasından dolayı, veriler araştırmacının önyargılarına veya önceden var olan bir kod şemasına bakılmaksızın kodlanmaktadır (Merriam, 2015; Thomas \& Murray, 2003). Araştırma verilerinin tematik analizi sürecinde ilk olarak, OSB olan çocuğa sahip anneler ile yapılan görüşmeler yazılı metne aktarılmıştır. Yazılı metinlerde herhangi bir karışılık meydana gelmemesi için görüşme formları annelere verilen rumuz isimler doğrultusunda sınıflandırılmıştır. Bu süreçte yazılı metinler araştırmaya katılan annelerin onayına sunularak yazılı metinlerin annelerin görüşlerini tam bir şekilde yansıtması sağlanmıştır. Yazılı metinler tekrar tekrar okunarak gözden geçirilmiş ve verilere ilişkin kodlar oluşturulmuştur. Ardından bu kodlar özellikleri doğrultusunda bir araya getirilerek kategorilere ulaşılmıştır. Kategorilerde yer alan kodlar frekanslarını içerecek şekilde tablolaştııılmıştır. Kategorilerin yorumlanmasında sık sık doğrudan alıntılara yer verilmiştir. Ulaşılan kodlar ve kategorilerin geçerlik ve güvenirliğinin sağlanmasında, verilerin araştırmaya katılan annelerin onayına sunulmasını yanı sıra alanında uzman akademisyenler tarafından incelenmesi yöntemine de başvurulmuştur. $\mathrm{Bu}$ kapsamda, nitel veri analizi sonucunda elde edilen kodlar ve kategoriler nitel araştırmalar konusunda uzman iki akademisyen tarafından ayrıca analiz edilmiştir. Araştırmacı ve uzman akademisyenlerin nitel veri analiz sonuçları arasındaki tutarlılığın incelenmesinde [Görüş birliği / (Görüş birliği + Görüş ayrılığı) x 100] formülü kullanılmıştır (Miles \& Huberman, 1994). Araştırmanın nitel verileri için hesaplanan görüş birliği $95 \%$ olarak tespit edilmiştir. Uyum sağlanamayan veriler için uzmanlar ve araştırmacı bir araya gelmiş ve analiz konusunda ortak noktalarda uzlaşma sağlanmıştır. 


\section{Bulgular}

Uygulama ve Kontrol Gruplarındaki Annelerin Yaşam Kalitesi Bakımından Ön Test Puanlarına Göre Düzeltilmiş Son Test Puanları Arasında Anlamlı Bir Farklılık Var mıdır?

Kontrol ve uygulama grubunda yer alan annelerin aile yaşam kalitesi ön test puanlarına göre düzeltilmiş son test puanları arasında anlamlı farklılık olup olmadığı tek yönlü kovaryans analizi ile incelenmiştir. Kovaryans (ANCOVA) analizi öncesinde aykırı değerler değerlendirilmiş; grupların ön-test, son-test ve izleme testi z puanlarının \pm 3.11 aralığında olduğu saptanmıştır. Ayrıca ANCOVA analizinin varsayımlarına (normallik, hata varyanslarının eşitliği ve regresyon doğrularının eğimlerinin homojenliği) bakılarak analiz öncesinde raporlanmıştır. Araştırmada normallik varsayımı Shapiro-Wilk testi ve Levene testi ile incelenmiş, dağılımın normale yakın olduğu $(p>.05)$ ve varyansların homojen dağıldığı sonucuna ulaşılmıştır $(p>.05)$. Son olarak bağımlı değişken ile kodeğişkenin regresyon eğimi eşitliği varsayımı $\left(F_{(1,20)}=0.012, p>.05\right)$ sağlanmıştır. Kovaryans analizine ilişkin tüm varsayımlar karşılandıktan sonra ön test puanlarının kontrol altında tutulması ile annelerin düzeltilmiş son test ortalama puanları arasındaki ilişki incelenmiştir. Kovaryans analizine ait ayrıntılı sonuçlar Tablo 4'te gösterilmiştir.

\section{Tablo 4}

Uygulama ve Kontrol Gruplarının Ön Test Puanlarına Göre Düzeltilmiş Son Test Puanlarının Karşılaştırılması

\begin{tabular}{lcccccc}
\hline \multicolumn{1}{c}{ Varyansın kaynağ } & Kareler toplamı & $s d$ & Kareler ortalamas1 & $F$ & $p$ & Kismi eta kare \\
\hline Denekleraras1 & 90.034 & 1 & 90.034 & 22.544 & .000 & .518 \\
Ön-test & 177.716 & 1 & 177.716 & 44.500 & .000 & .679 \\
UFA program1 & 75.267 & 1 & 75.267 & 18.847 & .000 & .473 \\
Hata & 83.867 & 21 & 3.994 & & & \\
Toplam & 158367.000 & 24 & & & & \\
\hline
\end{tabular}

Tablo 4'e göre, uygulama ve kontrol grubundaki annelerin düzeltilmiş ön-test puanlarına göre son-test aile yaşam kalitesi puan ortalamaları arasında .05 düzeyinde anlamlı bir farklılık olduğu belirlenmiştir $\left(F_{(1,2 l)}=\right.$ $18.84 ; p<.05)$. Uygulama ve kontrol grubunun düzeltilmiş aile yaşam kalitesi puanları arasında yapılan Bonferroni testi sonuçları, uygulama grubunda yer alan annelerin aile yaşam kalitesi ortalama puanlarının (86.64) kontrol grubundaki annelerin aile yaşam kalitesi puanlarından (79.40) daha yüksek olduğunu ortaya koymuştur.

\section{Uygulama Grubundaki Annelerin Yaşam Kalitesi Bakımından Ön Test, Son Test ve İzleme Testi Puanları} Arasında Anlamlı Bir Farklılık Var mıdır?

Uygulama grubundaki annelerin yaşam kalitesi bakımından ön test, son test ve izleme testi puanları arasında anlamlı bir farklılık olup olmadığı tekrarlayan ölçümler için ANOVA analizi ile incelenmiştir. Tablo 5 'te tekrarlayan ölçümler için ANOVA analizine ilişkin istatistiksel sonuçlar sunulmuştur.

\section{Tablo 5}

Uygulama Grubunun Ön Test, Son Test ve İzleme Testlerinin Karşılaştırılması

\begin{tabular}{lcccccc}
\hline \multicolumn{1}{c}{ Varyansın kaynağı } & Kareler toplam1 & $s d$ & Kareler ortalamas1 & $F$ & $p$ & Kismi eta kare \\
\hline Deneklerarası & 246512.250 & 1 & 246512.250 & 5141.352 & .000 & .998 \\
Grup (Uygulama) & 9.375 & 1 & 15.125 & 19.105 & .00 & .635 \\
Hata & 527.417 & 11 & 47.947 & & & \\
\hline
\end{tabular}

Tablo 5 incelendiğinde, uygulama grubunda yer alan annelerin aile yaşam kalitesi ölçümlerine ilişkin ön test, son test ve izleme testi puanları arasında anlamlı bir farklılık olduğu tespit edilmiştir $\left(F_{(1,11)}=19.105 ; p<\right.$ .05). Belirlenen farklılığın kaynağını belirlemek amacıyla çoklu karşılaştırma testi olan Bonferroni testinden yararlanılmıştır. Yapılan karşılaştırmalarda; ön test ve son test arasındaki anlamlı farklılığın son test lehine, ön test ve izleme testleri arasındaki anlamlı farklılığın ise izleme testi lehine olduğu belirlenmiştir. Buna karşın son test ölçümü ile izleme ölçümü puan ortalamalarının birbirine çok yakın olduğu, aralarında anlamlı bir fark olmadığı saptanmıştır.

\section{Uygulama Grubundaki Annelerin UFA Programı Sonrası Yaşam Kalitelerindeki Değişime Yönelik Görüşleri Nasıldır?}

Görüşmelere dâhil edilen her bir anne yaşam tarzı bakımından farklı olmasına rağmen, annelerin görüşleri uygulamalar sonucunda yaşam kalitelerindeki değişimi açıklayabilecek değişkenleri vurgulamaktadır. Yarı yapılandırılmış görüşmeler sonucunda anne görüşleri dört kategori etrafında toplanmıştır. UFA programı 
sonrasında anneler ile gerçekleştirilen görüşmeler sonucunda elde edilen kategoriler ve bu kategoriler altında yer alan kodlara ilişkin frekans değerleri Tablo 6'da verilmiştir.

\section{Tablo 6}

UFA Programı Sonrası Annelerin Yaşam Kalitesi Düzeylerine İlişkin Görüşleri

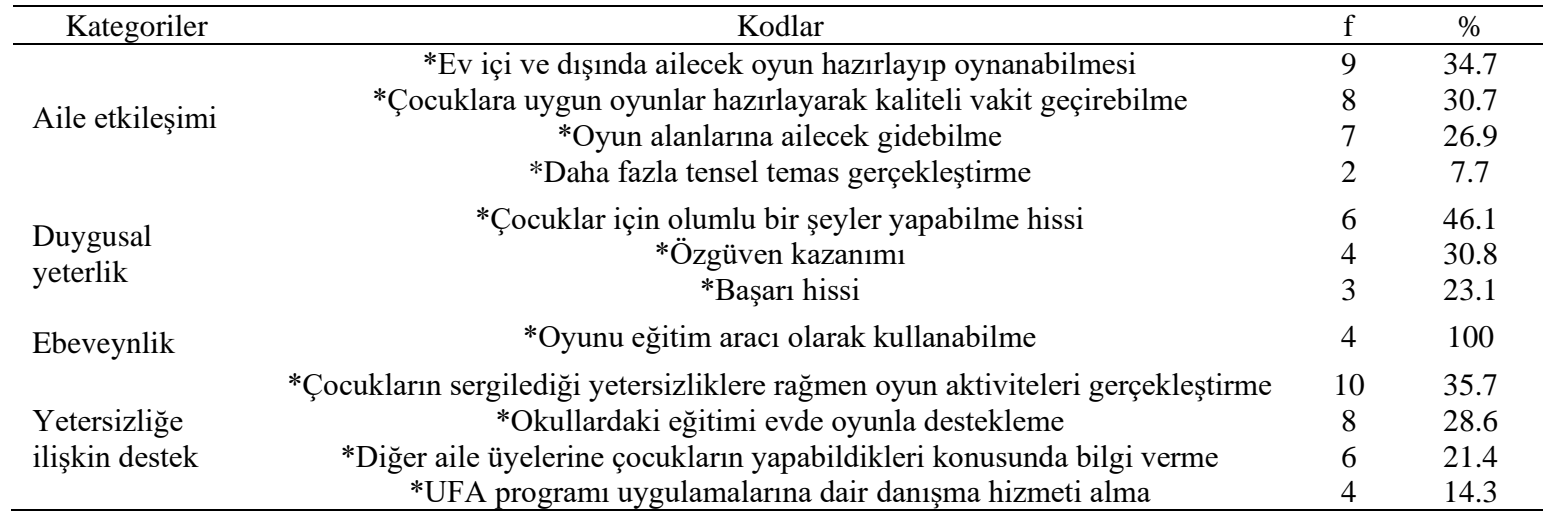

Annelerin çocuklarına uyguladıkları UFA programı ile yaşam kalitelerindeki olumlu değişimin daha derinlemesine incelenmesi amacıyla gerçekleştirilen görüşmelerde dört kategori elde edilmiştir. Bu kategoriler sırasıyla, Yetersizliğe İlişskin Destek, Aile Etkileşimi, Ebeveynlik ve Duygusal Yeterlik olmak üzere dört boyuttan oluşmaktadır. Finansal/Fiziksel/Materyal Yeterliği kapsamında annelere sorular yöneltilmesine rağmen anneler bu konuda uygulamalar sonrası bir değişim olmadığını ifade etmişlerdir. Dolayısıyla görüşme formu 5 boyuttan oluşmasına rağmen annelerden alınan cevaplar çerçevesinde 4 kategoriye ulaşılmıştır. Tablo 6'da yer alan frekans değerleri incelendiğinde, anne görüşlerine göre UFA programı uygulamaları sonrasında aile yaşam kalitesi açısından en büyük değişimin Yetersizliğe İlişkin Destek kategorisinde yaşandığı belirlenmiştir.

\section{Aile Etkileşimi Kategorisi}

Anneler ile gerçekleştirilen görüşmelerde, aile eğitimleri ile öğrenilen becerilerin aile üyeleri arasındaki etkileşimi artırıcı etki yarattığı belirlenmiştir. Bu kapsamda anne görüşleri, ev içi ve dışında ailecek oyun hazırlayıp oynanabilmesi, çocuklara uygun oyunlar hazırlayarak kaliteli vakit geçirebilme, oyun alanlarına ailecek gidebilme ve daha fazla tensel temas gerçekleştirme şeklinde kodlanmıştır. Anneler, aile yaşam kaliteleri üzerinde en olumlu etki yaratan kodun ev içi ve dlşında ailecek oyun hazırlayıp oynanabilmesi olduğunu ifade etmişlerdir. $\mathrm{Bu}$ koda ilişkin örnek bir anne görüşü aşağıda verilmiştir:

Çocuğumun eksik yanlarını iyi biliyorum... bazen dışarıda arkadaşlarıyla oynaması için çok çaba harcıyordum. Şimdi bu oyunları aile içinde özellikle evde olabilir dışarıda olabilir hazırlayabilirim. Bu bizi daha da yakınlaştırdığını hissediyorum. Babası bile toplu oyunlarda istekli.

Anne görüşlerine göre aile etkileşimi kategorisi altında aile yaşam kalitesini etkileyen diğer kod, "çocuklara uygun oyunlar hazırlayarak kaliteli vakit geçirebilme" şeklindedir. Bu koda ilişkin örnek bir anne görüşü aşağıda verilmiştir:

Oyunlar ben ve benim gibiler için ev işlerine zaman sağlamak için kullanılan bir aktiviteydi. Zaman geçirmek zaman yaratmak için çok işe yarayan bir şeydi. Şimdi zaman hemen geçmesini istemiyorum çünkü oğlum oynadıkça ben ondan daha çok oynamak istiyorum. Birlikte geçirdiğimiz zamanın değeri arttı sanki.

OSB olan çocuğa sahip ebeveynlerin oyun alanlarına çocukları ile katılma sıklıklarının düşük olduğu bilinmektedir. $\mathrm{Bu}$ durumun en temel nedenleri arasında çocukların engellerine bağlı ortaya çıkan davranış problemleri ve toplumun farkındalık düzeyinin düşüklüğü yer almaktadır. Anne görüşleri, UFA programı uygulamaları sonrasında bu kapsamda bazı değişikliklerin olduğunu göstermiş ve bu görüşler, "oyun alanlarına ailecek gidebilme” şeklinde kodlanmıştır. Bu koda ilişkin örnek bir anne görüşü aşağıda verilmiştir:

Anne olarak en zorlandığım şeylerden biri çocuğumla parka ve alişveriş merkezine gidememek. Çocuğumdan hep diğer çocuklar gibi oynamasını bekledim ve hem kendimi hem O’nu üzdüm. Eğitimlerde herkesin başarısının kendi yapabileceğiyle olduğunu öğrendik. Eğitimlerde onun 
yapabildikleri bana cesaret verdi, yine problemler oldu ancak bu kez oyun hazırlama yeteneğim var hemen dikkatini çekecek başka çareler bulabildim... parklara daha rahat gidebiliyorum.

OSB olan çocuklarda sık rastlanan yetersizliklerden biri temasa karşı gösterdikleri dirençtir. Ebeveyn ile çocukları arasındaki güvenli bağlanmanın direkt yollarından birinin temaslar ile gerçekleştiği düşünülmektedir. Anne görüşleri, uygulamalar sonrasında bu temasa karşı gösterilen dirençteki değişimi göstermiş ve bu görüşler, "daha fazla tensel temas gerçekleştirme" şeklinde kodlanmıştır. Bu koda ilişkin örnek bir anne görüşü aşağıda verilmiş̧ir:

Oğlumun dokunmaya karşı çok aşırı olmasa da özellikle benim dışımdakilerin dokunmasına temasına tepki veren bir çocuk. Ona sarılmak için eline tablet veya telefon verdiğim dahi olmuştur... ağlama sesi... Ancak oyunlarda keyif aldığı anlarda ona dokunulmasına kızmadığını tepki vermediğini fark ettim. Hatta eğitimi veren hocayla oyun oynadıklarında sarıldığını görmeyi hiç unutmayacağım. Oyunları onun ilgi ve isteğine göre hazırladığımda belki de bu problemi çözebileceğiz, ona doyasıya sarılabileceğim.

\section{Duygusal Yeterlik Kategorisi}

Anneler ile gerçekleştirilen görüşmelerde, uygulamalar ile öğrenilen becerilerin annelere duygusal açıdan kazanımlar sağladığı belirlenmiştir. Bu kapsamda anne görüşleri, çocuklar için olumlu bir şeyler yapabilme hissi, özgüven kazanımı ve başarı hissi olarak kodlanmıştır. Anneler bu kodlar arasında en fazla "çocuklar için olumlu bir şeyler yapabilme hissi" ne yönelik görüş bildirdiği belirlenmiştir. Bu koda ilişkin örnek bir anne görüşü aşağılda verilmiştir:

Bu uygulamalar öncesinde de oğlum için çok mücadele ettim ancak bu kez farklı bir şeyler hissederek oyunları oynayabildim. Ev hanımı olarak örnek verecek olursam, yemek tarifini Oğuz hocadan aldım ve artık o tarifi rahatça kullanabileceğim.

Duygusal yeterlik kategorisi altında kodlanan ve 4 annenin görüşlerinde yer verdiği kod "özgüven artışı" şeklindedir. Özellikle aile eğitim programı kapsamında hem teorik hem de uygulamalı olarak verilen eğitimler, annelerin uygulamalarda daha yeterli hale gelmelerinde önemli yer tutmuştur. Anne görüşleri, uygulamalar sonrasında özgüvenlerindeki değişimi göstermiş ve bu kodlamaya ilişkin örnek bir anne görüşü aşağıda verilmiştir:

Önceki ve sonraki diye düşündüğümde çok daha rahat ve esnek uygulama yapabilirim....bu konuda kendime olan güvenim arttı diyebilirim.

Tüm insanların olumlu bir durumu sürekli hale getirebilmelerinde başarı hissi önemli bir kavramdır. Uygulamalar sonrasında anne görüşlerine yansıyan başarı hissine yönelik ifadeler, örnek bir anne görüşü ile aşağıda verilmiştir:

Çocuğumun oyunu kazanması değil benim o oyunu ona oynatabilmem aslında en büyük kazanç bence.

Oyunda kazanan kaybeden vardır ya çocuğum eğlendikçe ben kazanıyorum aslında.

\section{Ebeveynlik Kategorisi}

Anneler ile gerçekleştirilen görüşmelerde, aile eğitimleri ile öğrenilen becerilerin annelere ebeveynlik rolünü zenginleştirecek kazanımlar sağladığı görülmüştür. Bu kapsamda yer alan anne görüşleri, "oyunu eğitim aracı olarak kullanabilme" şeklinde kodlanmıştır. Bu koda ilişkin örnek bir anne görüşü aşağıda verilmiştir:

Diğer annelerden ziyade ben özellikle annelik açısından bir şeyler kazandığımı düşünüyorum. Eskiden yine oyunlarla Legolar, sayılar, hayvan isimleri gibi şeyleri öğretmeye çalıştım. Ancak şimdi görüyorum ki çok sakin keyifsiz yapmışım. Şu anda her oyunda yaptırmak istediğimi planlayarak yaptırabiliyorum.

\section{Yetersizliğe İlişkin Destek Kategorisi}

Annelerin bu kategoriye ilişkin görüşleri, çocukların sergilediği yetersizliklere rağmen oyun aktiviteleri gerçekleştirme, okullardaki eğitimi evde oyunla destekleme, diğer aile üyelerine çocukların yapabildikleri konusunda bilgi verme ve UFA programı uygulamalarına dair danışma hizmeti alma şeklinde kodlanmıştır.

Çocukların sergilediği yetersizliklere rağmen oyun aktiviteleri gerçekleştirme koduna yönelik annelere ait bir görüş aşağıda verilmiştir:

...uygulamalar bittikten sonra özellikle aile eğitimlerinde de gördüğümüz oyunlar bizim için en büyük güç olduğunu öğrendik. Çocuğum oyunlarda başarılı olamayacak kadar iyi olmasa da yapabileceği 
mutlaka bir şeyler olduğunu düşünüyorum. Bu düşünce bile beni umutlandırıyor. Engeli olsa bile oyun oynamaktan vazgeçmek yok artık.

Okullardaki eğitimi evde oyunla destekleme koduna yönelik annelere ait bir görüş aşağıda sunulmuştur:

... oğlumun okuldaki eğitimini hep takip ederim. Ancak bu projeden sonra oynadıkları oyunlara daha fazla dikkat göstermekteyim. Okulda oynadıkları oyuna benzer oyunları ev ortamında yapabiliyorum. Elimden geldiği kadar oyun içinde eğitsel faydalar sağlanmasına çalışıyorum aslında okuldaki eğitimi evde destekleyebiliyorum...

Diğer aile üyelerine çocukların yapabildikleri konusunda bilgi verme koduna yönelik annelere ait bir görüş aşağıda sunulmuştur:

...komşu ziyaretleri olsun veli toplantıları olsun hep anlatılanları dinleyip kendi açımızdan olumlu şey anlatma şansımız olmazdı. Şimdi gittiğimiz eğitimleri çocuğumun oyunlardaki tavırlarından bahsetmek bana iyi geliyor, normalleşiyorum”.

Anneler ile gerçekleştirilen görüşmelerde, yapılan çalışmaların anlık bir etkiden ziyade, süreklilik gösterdiği; hayatları boyunca birçok açıdan yararlanabilecekleri kazanımlar sağladıkları belirlenmiştir. Bu kapsamda yer alan anne görüşleri, "UFA programı uygulamalarına dair danışma hizmeti alma" şeklinde kodlanmıştır. Bu koda ilişkin örnek bir anne görüşü aşağıda verilmiştir:

...Çocuklarımızla ilgili çok sayıda seminer ve çalışmalara gittik. Bir kısmı bize numarasını verdi ancak o samimiyeti bulup arayamadım. Burada her şey çok doğal ve her istediğimde arayıp oyunlarla ilgili soru sorabiliyorum. Bu durumun geçici olmadığını hissediyorum.

\section{Tartışma, Sonuç ve Öneriler}

Özel gereksinimi olan bireylerin yaşam kalitesine olan ilginin artması ile birlikte, yakın zamanda çalışmalar OSB olan bireylerde yaşam kalitesi kalitesine odaklanmaya başlamıştır. Buna ek olarak, yaşam kalitesi sadece OSB'den etkilenen bireyler için değil, aynı zamanda aile sistemleri ile ilgili olduğundan dolayı ailelerin yaşam kalitesi kalitesine yönelik araştırmalar ön plana çıkmıştır. Bu araştırmada, OSB olan çocuğa sahip anneler tarafından uygulanan UFA programının annelerin yaşam kaliteleri üzerinde etkili olup olmadığının incelenmesi amaçlanmıştır. Bu genel amaç doğrultusunda, OSB olan çocuğa sahip annelere araştırma öncesi UFA programı uygulama becerisi kazandırılmış ve anneler tarafından gerçekleştirilen uygulama süreci sonrası annelerin yaşam kalitesindeki değişimler belirlenmeye çalışılmıştır. Annelerin yaşam kalitesindeki değişimlerin derinlemesine incelenebilmesi amacıyla nicel bulgulara ek olarak nitel bulgular da elde edilmiştir.

Araştırma sonucu elde edilen nicel bulgular değerlendirildiğinde, anneler tarafindan uygulanan UFA programı sonrası, annelerin yaşam kalitesi düzeyinde olumlu yönde değişimlerin olduğu belirlenmiştir. Söz konusu olumlu değişimlerin araştırmadan üç hafta sonra elde edilen izleme testinde devam ettiği görülmüştür. Nitel bulgular analiz edildiğinde ise annelerin; aile eğitimleri ve UFA programı aracılığıyla yetersizliğe ilişkin destek alma, çocuklarıyla UFA programında yer alan uygulamalarda olumlu etkileşimler kurma, çocukları için bir şey yapabilme hissi ve çocuklarıyla ev içinde veya dışında uygulayabilecekleri etkileşime dayalı aktiviteler öğrenme gibi nedenlerden dolayı UFA programı sonrası yaşam kalitelerinde olumlu yönde değişimler olduğunu ifade ettikleri belirlenmiştir. Araştırmada annelerin yaşam kalitesi düzeyine ilişkin elde edilen bu olumlu sonuçların birtakım olası sebepleri olduğu değerlendirilmektedir. Öncelikle annelerin UFA programı sırasında OSB olan çocuklarının gelişim alanlarında ortaya çıkan olumlu değişimlere tanıklık etmelerinin yaşam kaliteleri üzerinde olumlu yönde bir katkısının olduğu düşünülmektedir. Alanyazın incelendiğinde, UFA programına katılımın OSB olan çocukların sosyal etkileşim ve iletişim becerileri, davranış sorunları, tekrarlayan davranışları ve bilişsel becerileri gibi birçok gelişim alanı üzerinde olumlu yönde değişimler oluşturduğunun öne sürüldüğü görülmektedir (Alexander vd., 2011; Bahrami vd., 2012; Bass vd., 2009; Brookman vd., 2003; Chu \& Pan, 2012; Gabriels vd., 2012; Hameury vd., 2010; Movahedi vd., 2013; Nicholson vd., 2011; Pan, 2010; Pitetti vd., 2007; Prupas \& Reid, 2001; Yarımkaya vd., 2017). UFA programının OSB olan çocuklar üzerindeki söz konusu etkileri, mevcut araştırmaya katılan OSB olan çocuklar üzerinde de gözlenmiş ve annelerin UFA programı sonrası çocuklarının gelişim alanlarında gösterdikleri gelişimden duydukları memnuniyeti içeren ifadeler belirttikleri görülmüştür. Özellikle UFA programı sonucunda "aile etkileşimleri" ve "yetersizliğe ilişkin destek" kategorilerinde toplanan görüşme verileri, OSB olan çocukların UFA programı sonrası sergilediği gelişime tanıklık eden annelerin memnuniyetlerini gösterir bir nitelik taşımaktadır. Alanyazın incelendiğinde, UFA ve aile katılımı üzerine yapılan çalışmaların (Demirdağ, 2010; İlhan, 2010; Sukan, 2013) genellikle zihinsel yetersizliği 

FİİKSEL AKTIVITTELERIN ANNELERIN YAŞAM KALİTESINE ETKİSİ

olan bireyler üzerine kurgulandığı görülmektedir. Her ne kadar OSB, UFA ve aile katılımı üzerine yürütülmemiş olsa da söz konusu çalışmaların sonuçları mevcut araştırmada elde edilen sonuçlarla benzer nitelik göstermekte ve zihinsel yetersizliği olan çocukları ile birlikte beden eğitimi ve spor etkinliklerine katılan ebeveynlerin kaygı düzeyindeki olumlu değişimleri ortaya koymaktadır.

OSB olan bir çocuğa sahip olmak, ailelerin artan stres, uyku yoksunluğu ve yorgunluklarının yanı sıra fiziksel ve zihinsel işlevlerden ödün vermesi anlamına da gelmektedir (Giallo vd., 2013; Seymour vd., 2013). Toplumun ön yargıları, artan bakım sorumlukları ve OSB olan çocukların eğitimi sürecindeki yüksek mali talepler ailelerin sosyalleşme firsatlarını azaltabilir ve çevrelerinde olumlu değişiklikler yapma kapasitelerini engelleyebilir (Gray, 2008; McCann vd., 2012; Sawyer vd., 2010; Sharpe \& Baker, 2007). Tüm bu olumsuz nedenler annelerin yaşam kalitesi düzeyinde gerilemeye sebep olmakta ve ailelerin yaşam kalitelerinde normal gelişim gösteren bireylere göre anlamlı bir düşüş gözlenmesine yol açmaktadır (Beadle-Brown vd., 2009; Yirmiya \& Shaked, 2005). Bu noktada, ailelerin OSB çocuklarının gelişimlerine tanıklık etmelerinin yanı sıra kendilerinin de sosyal ve duygusal anlamda gelişim göstermesine katkı sunacak (Currie, 2018; Verhoef \& Love, 1994) UFA programı gibi uygulamalara katılımı, onların sorunların üstesinden gelmesinde sosyal bir destek rolü görebilmektedir.

Araştırmada annelerin yaşam kalitesi düzeyine ilişkin elde edilen olumlu sonuçların olası sebeplerinden bir diğerinin ise annelere UFA programı uygulama becerisinin kazandırılması olduğu değerlendirilmektedir. Araştırma kapsamında UFA programının anneler tarafından OSB olan çocuklara sunulması hedeflenmiştir. Annelerin OSB olan çocuklarına UFA programını uygulamakta yeterli hale gelmeleri için aile eğitim programı düzenlenmiş ve program kapsamında annelere UFA programının uygulama öncesinde yapılması gereken hazırlıklar ve uygulama sürecinde izlenmesi gereken basamaklarının öğretimi gerçekleştirilmiştir. Bu sayede, annelerin araştırma sürecinde olduğu gibi günlük yaşamda da çocuklarıyla birlikte UFA programında yer alan uygulamaları gerçekleştirmeleri amaçlanmıştır. Nitekim anneler ile gerçekleştirilen görüşmelerde, annelerin günlük yaşamda UFA programı sırasında öğrendikleri uygulamaları çocuklarıyla rahatlıkla gerçekleştirdikleri ve bu durumun onların yaşam kalitesi düzeyine olumlu katkılar sunduğu yönünde ifadelere ulaşılmıştır. Araştırma kapsamında ulaşılan bu ifadeler, annelerin OSB olan çocuklarıyla birlikte gerçekleştirdikleri UFA uygulamaları ile yaşamlarının daha konforlu hale geldiğine kanıt olarak gösterilebilir.

Alanyazında, aile eğitim programları ile ebeveynlere OSB olan çocuklarına yönelik uygulayabilecekleri çeşitli uygulamaların öğretim becerisinin kazandırıldığı çalışmalara rastlamak mümkündür (Bergan vd., 1983; Charlop-Christy \& Carpenter, 2000; Ward-Horney \& Sturmey, 2008). Ancak, OSB olan çocuğa sahip ailelere UFA programı uygulama becerisi kazandırmayı amaçlayan sınırlı sayıda çalışmaya rastlanmaktadır (Esentürk, 2019; Solomon vd., 2014). Bu sınırlı sayıdaki çalışmalarda, ailelere UFA programı uygulama becerisi kazandırılmakta ve aileler tarafından uygulanan UFA programı sonrası OSB olan çocukların iletişim becerilerindeki değişimlere yönelik sonuçlar sunulmaktadır. Mevcut araştırmada, Esentürk (2019) ve Solomon ve diğerleri (2014) tarafından yürütülen çalışmalardan farklı olarak, OSB olan çocukların gelişim alanları üzerine değil annelerin yaşam kaliteleri üzerine odaklanılmış ve anneler tarafından sunulan UFA programının annelerin yaşam kaliteleri üzerindeki etkilerine yönelik sonuçlara ulaşılmıştır.

Yapılan bu araştırmada sonuç olarak, OSB olan çocuğa sahip anneler tarafından uygulanan UFA programının annelerin yaşam kaliteleri üzerinde olumlu yönde bir etki oluşturduğu belirlenmiştir. Deneysel olarak ortaya konulan nicel bulgulara ek olarak araştırmada elde edilen nitel bulgular, annelerin yaşam kalitelerindeki olumlu değişimin farklı yönlerden incelenmesine imkân sunmuştur. Araştırma kapsamında ulaşılan bu anlamlı ve olumlu sonuçlara karşın, sonuçlar yorumlanırken araştırmanın birtakım sınırlılıklara sahip olduğu göz önünde bulundurulmalıdır. İlk olarak, araştırma 12'si uygulama, 12'si kontrol grubu olmak üzere OSB olan çocuğa sahip 24 anne üzerinde gerçekleştirilmiştir. Bu durum araştırma sonuçlarının genellenebilirliği açısından bir sınırlılık olarak düşünülmektedir. Bunun yanı sıra, araştırma kapsamında UFA programının anneler tarafından güvenilir olarak uygulanıp uygulanmadığının belirlenmesi amacıyla ayrıca veri elde edilmemiştir. Her ne kadar uygulamalar boyunca anneler araştırmacılar tarafından sürekli gözlenmiş ve anında dönütler verilerek eğitimlerde kazanımların dışına çıkılmamasına dikkat edilmiş olsa da bu durum UFA programının anneler tarafından güvenilir bir şekilde uygulanıp uygulanmadığına ilişkin bir veri bulunmamaktadır. Araştırma sonuçları ve sınırlılıkları doğrultusunda, uygulamaya ve bundan sonraki yapılacak çalışmalara yönelik izleyen önerilerde bulunulabilir:

1. Araştırma öncesi anneler, UFA programı sunma yeterliliği kazanmaları amacıyla üç gün süreyle teorik ve uygulamalı aile eğitimi programına tabi tutulmuş olsalar da bazı günler annelerin aktivitelerin hazırlık, sunma ve bitiriş bölümlerinde karışıklık yaşadığ 1 gözlemlenmiştir. İlerleyen günlerde bu sorun, anneler 
ile aktivite öncesi hazırlık konuşmaları yapılarak çözümlenmiştir. Bundan sonraki çalışmalarda bu duruma dikkat edilerek ilk çalışmadan itibaren aktivite öncesi anneler ile hazırlık görüşmeleri yapılabilir.

2. Araştırmada annelerin UFA programını uygulayabilmesi için ailelere verilen aile eğitimi kitabı büyük katkı sunmuştur. Anneler, UFA programı uygulama becerisi kazanma eğitimlerinin yanı sıra aile eğitimi el kitabından da faydalanmış ve çocuklarına UFA programını başarılı bir şekilde uygulayabilmiştir. Bu bağlamda, mevcut araştırmada ya da farklı bir çalı̧̧mada kullanılan aile eğitimi el kitabı gibi materyaller web tabanlı uygulamalara dönüştürülerek ailelerin erişimine sunulabilir.

3. OSB olan çocuğa sahip ebeveynlere, UFA programının çocukları ve kendi gelişimleri üzerindeki etkileri hakkında çeşitli bilgilendirme çalışmaları yapılabilir ve OSB olan çocuğa sahip ailelerin çocuklarına UFA programını kolaylıkla sunabileceklerine ilişkin farkındalık oluşturulabilir.

4. UFA programı 12 hafta boyunca haftada üç gün 40 'ar dakika süreyle uygulanmıştır. UFA programı bundan sonra yapılacak çalışmalarda toplam süre ve oturum sayıları arttırılarak uygulanabilir.

5. Araştırmada annelerin OSB olan çocuklarına UFA programını sunabilmeleri için annelere ısınma aktiviteleri, eğitsel oyunlar, istasyon parkurları, sportif yarışmalar, işlevsel hareketler ve esnetme-soğuma çalışmaları gibi birtakım fiziksel aktivite örnekleri gösterilmiştir. Ebeveynlerin faydalanması için OSB olan çocuklara yönelik farklı fizikse aktivitelerin uyarlamasını içeren bir el kitabı oluşturulabilir. OSB olan çocukların anneleri ile ev ortamında geçirdiği süreler ve pandemi süreci göz önüne alındığında, ev ortamında yapılabilecek ev temelli fiziksel aktivite ve oyun örnekleri el kitabına dâhil edilebilir.

\section{Yazarların Katkı Düzeyleri}

Çalışmanın yazarları, çalışma konusunu belirleme, araştırma deseni, veri toplama, verilerin analizi ve çalı̧̧anın raporlanması görevlerinin tamamında birlikte çalışmışlardır.

\section{Teșekkür}

Araştırma süresince her bir fiziksel etkinlik çalışmasına son derece istekli bir şekilde katılan kıymetli annelerimize ve özel çocuklarımıza araştırmaya olan katılımlarından dolayı teşekkür ederiz. 
OTİZM SPEKTRUM BOZUKLUĞU OLAN ÇOCUĞA SAHIIP ANNELERİN UYGULADIĞI UYARLANMIŞ FIZİKSEL AKTIVITELERIN ANNELERIN YAŞAM KALITTESINE ETKİSI

\section{Kaynaklar}

Acar, C., Tekin-Iftar, E., \& Yikmis, A. (2017). Effects of mother-delivered social stories and video modeling in teaching social skills to children with autism spectrum disorders. The Journal of Special Education, 50(4), 215-226. https://doi.org/10.1177/0022466916649164

Alexander, M. G. F., Dummer, G. M., Smeltzer, A., \& Denton, S. J. (2011). Developing the social skills of young adult special olympics athletes. Educationand Training in Autism and Developmental Disabilities, 46(2), 297-310.

https://www.jstor.org/stable/pdf/23879699.pdf?casa token=vt2nKGtW4sAAAAAA:PUHAbL7161YLE cHDwvNri7IW2GBNa4VAlw4919y42EfkvgjxYY8sWqCZkyjP0v8hYfWZKvW6kvVvQ_PzEKD3JpV oFzGluJOsR0UhkcIbu6fkI-PfxCGF

American Psychiatric Association. (2013). Diagnostic and statistical manual of mental disorders (5th ed.). American Psychiatric Publishing.

Baghdadli, A., Pry, R., Michelon, C., \& Rattaz, C. (2014). Impact of autism in adolescents on parental quality of life. Quality of Life Research, 23(6), 1859-1868. https://doi.org/10.1007/s11136-014-0635-6

Bahrami, F., Movahedi, A., Marandi, S. M., \& Abedi, A. (2012). Kata techniques training consistently decreases stereotypy in children with autism spectrum disorder. Research in Developmental Disabilities, 33(4), 1183-1193. https://doi.org/10.1016/j.ridd.2012.01.018

Baker, B. L., \& Brightman, R. P. (1984). Training parents of retarded children: Program specific outcomes. Journal of Behavior Therapy and Experimental Psychiatry, 15(3), 255-260. https://doi.org/10.1016/00057916(84)90034-X

Baker, B. L., \& McCurry, M. C. (1984). School-based parentt raining: An alternative for parents predicted to demonstrate low teaching proficiency following group training. Education \& Training of the Mentally Retarded, 19(4),

261-267. https://www.jstor.org/stable/pdf/23877268.pdf?casa token=KvaTZc0COjkAAAAA:hX2CHtUV74nZS RP9T3u UelaINHyxOBNySESqlA2ajrQvVCUxAQaGVuHTb3zGNZRwHEUCRpJD8jDdAqwwgRxpf1Gf5yRkxBkJd vc8H5CasAh0Z0jOk2

Bass, M. M., Duchowny, C. A., \& Llabre, M. M. (2009). The effect of therapeutic horseback riding on social functioning in children with autism. Journal of Autism and Developmental Disorders, 39(9), 1261-1267. https://doi.org/10.1007/s10803-009-0734-3

Beadle-Brown, J., Murphy, G., \& DiTerlizzi, M. (2009). Quality of life for the Camberwell cohort. Journal of Applied Research in Intellectual Disabilities, 22(4), 380-390. https://doi.org/10.1111/j.1468$\underline{\text { 3148.2008.00473.x }}$

Bergan, J. R., Neumann II, A. J., \& Karp, C. L. (1983). Effects of parent training on parent in struction and child learning of intellectual skills. Journal of School Psychology, 21(1), 31-39. https://doi.org/10.1016/00224405(83)90064-X

Block, M. E. (2007). A teacher's guide to including students with disabilities in regular physical education. Paul H. Brookes Publishing.

Bogdan, R., \& Biklen, S. K. (2007). Pearson qualitative research for education: An introduction to theories and methods. Pearson Education Inc.

Brookman, L., Boettcher, M., Klein, E., Openden, D., Koegel, R. L., \& Koegel, L. K. (2003). Facilitating social interactions in a community summer camp setting for children with Autism. Journal of Positive Behavior Interventions, 5(4), 249-252. https://doi.org/10.1177/10983007030050040801

Büyüköztürk, Ş. (2007). Sosyal bilimler için veri analizi el kitabı [Data analysis hand book for social sciences]. Pegem A Yayıncilık.

Charlop-Christy, M. H., \& Carpenter, M. H. (2000). Modified incidental teaching sessions: A procedure for parents to increase spontaneous speech in their children with autism. Journal of Positive Behavior Interventions, 2(2), 98-112. https://doi.org/10.1177/109830070000200203 
Chu, C. H., \& Pan, C. Y. (2012). The effect of peer-and sibling-assisted aquatic program on interaction behaviors and aquatic skills of children with autism spectrum disorders and their peers/siblings. Research in Autism Spectrum Disorders, 6(3), 1211-1223. https://doi.org/10.1016/j.rasd.2012.02.003

Creswell, J. W. (2005). Educational research. Planning, conducting and evaluating quantitative and qualitative research. Pearson Education.

Creswell, J. W., \& Plano-Clark, V. L. (2014). Karma yöntem araştırmaları: Tasarımı ve yürütülmesi [Mixed method researches: Design and implementation]. (A. Delice, Çev.). Anı Yayınc1lık.

Currie, J. (2018) Radical leisure: How mothers gain well-being and control through participation in exercise classes. Common Ground Research Networks, Champaign, IL.

Demirdağ, M. (2010). Sporun öğretilebilir zihinsel engelli çocukların sosyalleşmeleri üzerine etkisinin araştırllması [A research on effects of sport on socialization of educatible mental disabled children] (Tez Numarası: 289039) [Yüksek lisans tezi, Dumlupınar Üniversitesi]. Yükseköğretim Kurulu Ulusal Tez Merkezi.

Diken, İ. H. (2009). Turkish mothers' self-efficacy beliefs and styles of interactions with their children with language delays. Early Child Development and Care, 179(4), 425-436. https://doi.org/10.1080/03004430701200478

Ekici, G. (2008). Sınıf yönetimi dersinin öğretmen adaylarının öğretmen öz-yeterlik algı düzeyine etkisi [The effects of the classroom management lesson on preservice teachers' teacher sense of self-efficacy]. Hacettepe Üniversitesi Ĕ̈itim Fakültesi Dergisi, 35, 98-110.

Esentürk, O. K. (2019). Anneler tarafindan uygulanan uyarlanmış fiziksel aktivite programının otizm spektrum bozukluğu tanılı çocukların iletişim becerileri üzerindeki etkililiğinin incelenmesi [Examination of the effectiveness of adapted physical activity program implemented by mothers on communication skills of children with autism spectrum disorder] (Tez Numaras1: 590316) [Doktora tezi, Gazi Üniversitesi]. Yükseköğretim Kurulu Ulusal Tez Merkezi.

Farnik, M., Brozek, G., Pierzchała, W., Zejda, J. E., Skrzypek, M., \& Walczak, Ł. (2010). Development, evaluation and validation of a new instrument for measuremen tquality of life in the parents of children with chronic disease. Health and Quality of Life Outcomes, 8(151), 1-9. https://doi.org/10.1186/1477-7525-8-151

Fragala-Pinkham, M. A., Haley, S. M., \& O’Neil, M. E. (2008). Group swimming and aquatic exercise programme for children with autism spectrum disorders: A pilot study. Developmental Neurorehabilitation, 14(4), 230-241. https://doi.org/10.3109/17518423.2011.575438

Gabriels, R. L., Agnew, J. A., Holt, K. D., Shoffner, A., Pan, Z., Ruzzano, S., Clayton, H. C., \& Mesibov, G. (2012). Pilot study measuring the effects of therapeutic horseback riding on school-age children and adolescents with autism spectrum disorders. Research in Autism Spectrum Disorders, 6(2), 578-588. https://doi.org/10.1016/j.rasd.2011.09.007

Garcia-Villamisar, D. A., \& Dattilo, J. (2010). Effects of a leisure program on quality of life and stress of individuals with ASD. Journal of Intellectual Disability Research, 54(7), 611-619. https://doi.org/10.1111/j.1365-2788.2010.01289.x

Giallo, R., Wood, C. E., Jellett, R., \& Porter, R. (2013). Fatigue, wellbeing and parental self-efficacy in mothers of children with an autism spectrum disorder. Autism, 17(4), 465-480. https://doi.org/10.1177/1362361311416830

Gray, D. E. (2008). Perceptions of stigma: The parents of autistic children. Sociology of Health \& Illness, 15(1), 102-120. https://doi.org/10.1111/1467-9566.ep11343802

Greenspan, S. I. (1992). Infancy and early childhood: Thepractice of clinical assessment and intervention with emotional and developmental challenges. International Universities Press, Inc.

Gutman, S. A., Raphael-Greenfield, E. I., \& Rao, A. K. (2012). Effect of a motor-based role-play intervention on the social behaviors of adolescents with high-functioning autism: Multiple-baseline single-subject design. American Journal of Occupational Therapy, 66(5), 529-537. https://doi.org/10.5014/ajot.2012.003756 
Hameury, L., Delavous, P., Teste, B., Leroy, C., Gaboriau, J. C., \& Berthier, A. (2010). Équithérapie et autisme. Annales Médico-psychologiques, Revue Psychiatrique, 168(9), 655-659. https://doi.org/10.1016/j.amp.2009.12.019

Hastings, R. P., \& Brown, T. (2002). Behavior problems of children with autism, parental self-efficacy, and mental health. American Journal on Mental Retardation, 107(3), 222-232. https://doi.org/10.1352/0895$\underline{8017(2002) 107<0222: \mathrm{BPOCWA}>2.0 . \mathrm{CO} ; 2}$

Hoffman, L., Marquis, J., Poston, D., Summers, J. A., \& Turnbull, A. (2006). Assessing family outcomes: Psychometric evaluation of the Beach Center Family Quality of Life Scale. Journal of Marriage and Family, 68(4), 1069-1083. https://doi.org/10.1111/j.1741-3737.2006.00314.x

Hurth, J., Shaw, E., Izeman, S. G., Whaley, K., \& Rogers, S. J. (1999). Areas of agreement about effective practices among programs serving young children with autism spectrum disorders. Infants and Young Children, 12(2), 17-26.

Ingersoll, B., \& Hambrick, D. Z. (2011). The relationship between the broader autismphenotype, child severity, and stres and depression in parents of children with autism spectrum disorders. Research in Autism Spectrum Disorders, 5(1), 337-344. https://doi.org/10.1016/j.rasd.2010.04.017

İlhan, L. (2010). The effect of the participation of educable mentally retarded children in the special physical education classes upon the anxiety levels of the parents of the children. Ovidius University Annals, Series Physical Education and Sport/Science, Movement and Health, 10(2), 304-309.

Karasar, N. (2015). Bilimsel araştırma yöntemi [Scientific research method]. Nobel Yayın Dağıtım.

Kunzi, K. (2015). Improving social skills of adults with autism spectrum disorder through physical activity, sports, and games: A review of the literature. Adultspan Journal, 14(2), 100-113. https://doi.org/10.1002/adsp.12008

Lee, G. K., Lopata, C., Volker, M. A., Thomeer, M. L., Nida, R. E., Toomey, J. A., Chow, S. Y., \& Smerbeck, A. M. (2009). Health-related quality of life of parents of children with high-functioning autism spectrum disorders. Focus on Autism and Other Developmental Disabilities, 24(4), 227-239. https://doi.org/10.1177/1088357609347371

Lequia, J., Machalicek, W., \& Lyons, G. (2013). Parent education intervention results in decreased challenging behavior and improved task engagement for students with disabilities during academic tasks. Behavioral Interventions, 28(4), 322-343. https://doi.org/10.1002/bin.1369

Liamputtong, P. (2009). Qualitative data analysis: Conceptual and practical considerations. Health Promotion Journal of Australia, 20(2), 133-139. https://doi.org/10.1071/HE09133

Mazurik-Charles, R., \& Stefanou, C. (2010). Using paraprofessionals to teach social skills to children with autism spectrum disorders in the general education classroom. Journal of Instructional Psychology, 37(2), 161169.

McCann, D., Bull, R., \& Winzenberg, T. (2012). The daily patterns of time use for parents of children with complex needs: A systematic review. Journal of Child Health Care, 16(1), 26-52. https://doi.org/10.1177/1367493511420186

Meltzer, E. O. (2001). Quality of life in adults and children with allergic rhinitis. Journal of Allergy and Clinical Immunology, 108(1, Supplement), 45-53. https://doi.org/10.1067/mai.2001.115566

Menear, K. S., \& Neumeier, W. H. (2015). Promoting physical activity for students with autism spectrum disorder: Barriers, benefits, and strategies for success. Journal of Physical Education, Recreation \& Dance, 8(3), 43-48. https://doi.org/10.1080/07303084.2014.998395

Meral, B. F. (2011). Gelişimsel yetersizliği olan çocukların annelerinin aile yaşam kalitesi algılarının incelenmesi [The examination of the family quality of life perceptions of mothers who have children with disabilities] (Tez Numarası: 298176) [Doktora tezi, Anadolu Üniversitesi]. Yükseköğretim Kurulu Ulusal Tez Merkezi. 
Meral, B. F., \& Cavkaytar, A. (2013). Beach center aile yaşam kalitesi ölçeğinin Türkçe uyarlama, geçerlik ve güvenirlik çalışması [Turkish adaptation, validity and reliability study of the beach center family quality of life scale]. Eğitim ve Bilim, 38(170), 48-60. http://egitimvebilim.ted.org.tr/index.php/EB/article/view/910/544

Merriam S. B. (2015). Qualitative research: A guide to design and implementation (4th ed.). Jossey-Bass.

Miles, M. B., \& Huberman, A. M. (1994). Qualitative data analysis. Sage Publications.

Movahedi, A., Bahrami, F., Marandi, S. M., \& Abedi, A. (2013). Improvement in social dysfunction of children with autism spectrum disorder following long term kata techniques training. Research in Autism Spectrum Disorders, 7(9), 1054-1061. https://doi.org/10.1016/j.rasd.2013.04.012

Mugno, D., Ruta, L., D’Arrigo, V. G., \& Mazzone, L. (2007). Impairment of quality of life in parents of children and adolescents with pervasive developmental disorder. Health and Quality of Life Outcomes, 5(22), 19. https://doi.org/10.1186/1477-7525-5-22

National Autism Center. (2015). National standards report 2. Randolph. Massachusetts: NationalAutism Center. https://www.nationalautismcenter.org/national-standards-project/results-reports/

Nicholson, H., Kehle, T. J., Bray, M. A., \& Van Heest, J. (2011). The effects of antecedent physical activity on the academic engagement of children with autism spectrum disorder. Psychology in the School, 48(2), 198-213. https://doi.org/10.1002/pits.20537

Olçay- Gül, S. (2016). The combined use of video modeling and social stories in teaching social skills for individuals with intellectual disability. Educational Sciences: Theory and Practice, 16(1), 83-107. https://doi.org/10.12738/estp.2016.1.0046

Olçay-Gül, S., \& Tekin-Iftar, E. (2016). Family generated and delivered social story intervention: Acquisition, maintenance, and generalization of social skills in youths with ASD. Educationand Training in Autism and Developmental Disabilities, 51(1), 67-78. https://doi.org/10.1002/pits.20537

Osterling, J., \& Dawson, G. (1994). Early recognition of children with autism: A study of first birthday home videotapes. Journal of Autism and Developmental Disorders, 24(3), 247-257. https://doi.org/10.1007/BF02172225

Özer, S. D. (2010). Engelliler için beden eğitimi ve spor [Physical education and sports for the disabled]. Nobel Yayın Dağıtım.

Pan, C. Y. (2010). Effects of water exercise swimming program on aquatic skills and social behaviors in children with autism spectrum disorders. Autism, 14(1), 9-28. https://doi.org/10.1177/1362361309339496

Petrus, C., Adamson, S. R., Block, L., Einarson, S. J., Sharifnejad, M., \& Harris, S. R. (2008). Effects of exercise interventions on stereotypic behaviours in children with autism spectrum disorder. Physiotherapy Canada, 60(2), 134-145. https://doi.org/10.3138/physio.60.2.134

Pitetti, K. H., Rendoff, A. D., Grover, T., \& Beets, M. W. (2007). The efficacy of a 9-month treadmill walking program on the exercise capacity and weight reduction for adolescents with severe autism. Journal of Autism and Developmental Disorders, 37(6), 997-1006. https://doi.org/10.1007/s10803-006-0238-3

Prupas, A., \& Reid, G. (2001). Effects of exercise frequency on stereotypic behaviors of children with developmental disabilities. Education and Training in Mental Retardation and Developmental Disabilities, 36(2), 196-206. https://www.jstor.org/stable/pdf/23879735.pdf?casa token=8cqViM4jPkAAAAA:5fGm2e3vWtCoLMXBi0UweeUGrP3uuR4n2f5LSAdIckRrjvcBltRXjcALj3D_pLBHG9r9yJbUvhjqNByUHK4GvxgBqe8XVgb1qxwa_6GjcRxc76Zw3Bk

Rosenberg, S. A., Robinson, C. C., \& Beckman, P. J. (1986). Measures of parent-infant interaction: An overview. Topics in Early Childhood Special Education, 6(2), 32-43. https://doi.org/10.1177/027112148600600204

Sameroff, A. J., \& Fiese, B. H. (2000). Transactional regulation: The developmental ecology of early intervention. In J. P. Shonkoff \& S. J. Meisels (Eds.), Handbook of early childhood intervention (pp. 135-159). Cambridge University. 
Sawyer, M. G., Bittman, M., La Greca, A. M., Crettenden, A. D., Harchak, T. F., \& Martin, J. (2010). Time demands of caring for children with autism: What are the implications for maternal mental health? Journal of Autism and Developmental Disorders, 40(5), 620-628. https://doi.org/10.1007/s10803-009$\underline{0912-3}$

Schalock, R. L. (2000). Three decades of quality of life. Focus on Autism \& Other Developmental Disabilities, 15(2), 116-128. https://doi.org/10.1177/108835760001500207

Schieve, L. A., Blumberg, S. J., Rice, C., Visser, S. N., \& Boyle, C. (2007). The relationship between autism and parenting stress. Pediatrics, 119(1), 114-121. https://doi.org/10.1542/peds.2006-2089Q

Schultheis, S. F., Boswell, B. B., \& Decker, J. (2000). Successful physical activity programming for students with autisim. Focus on Autisim Other Development Disability, 15(3), 159-162. https://doi.org/10.1177/108835760001500306

Seymour, M., Wood, C., Giallo, R., \& Jellett, R. (2013). Fatigue, stres and coping in mothers of children with an autism spectrum disorder. Journal of Autism and Developmental Disorders, 43(7), 1547-1554. https://doi.org/10.1007/s10803-012-1701-y

Sharpe, D. L., \& Baker, D. L. (2007). Financial issues associated with having a child with autism. Journal of Family and Economic Issues, 28(2), 247-264. https://doi.org/10.1007/s10834-007-9059-6

Sherrill, C. (2004). Adapted physical activity, recreation and sport. McGraw-Hill.

Shu, B. C., \& Lung, F. W. (2005). The effect of support group on the mental health and quality of life for mothers with autistic children. Journal of Intellectual Disability Research, 49(1), 47-53. https://doi.org/10.1111/j.1365-2788.2005.00661.x

Solomon, R., Van Egeren, L. A., Mahoney, G., Huber, M. S. Q., \& Zimmerman, P. (2014). Play Project home consultation intervention program for young children with autism spectrum disorders: A randomized controlled trial. Journal of Developmental and Behavioral Pediatrics, 35(8), 475-485. https://doi.org/10.1097/DBP.0000000000000096

Sowa, M., \& Meulenbroek, R. (2012). Effects of physical exercise on autism spectrum disorders: A meta analysis. Research in Autism Spectrum Disorders, 6(1), 46-57. https://doi.org/10.1016/j.rasd.2011.09.001

Srinivasan, S. M., Pescatello, L. S., \& Bhat, A. N. (2014). Current perspectives on physical activity and exercise recommendations for children and adolescents with autism spectrum disorders. Physical Therapy, 94(6), 1-46. https://doi.org/10.2522/ptj.20130157

Staples, K. L., Reid, G., Pushkarenko, K., \& Crawford, S. (2011). Physically active living for individuals with ASD. In J. L. Matson \& P. Sturmey (Eds.), International handbook of autism and pervasive developmental disorders (pp. 397-412). Springer Science and Business Media. https://doi.org/10.1007/978-1-4419-8065-6_25

Sukan, H. D. (2013). Fiziksel aktivitenin zihinsel engelli çocukların sosyalleşmesine etkisi [The effect of physical activity on socialization of children with intellectual disabilities] (Tez Numaras1: 340898) [Yüksek lisans tezi, Muğla Sitkı Koçman Üniversitesi]. Yükseköğretim Kurulu Ulusal Tez Merkezi

The National Professional Development Center. (2014). Evidence-based practices. http://autismpdc.fpg.unc.edu/evidence-based-practices

Thomas, R., \& Murray. (2003). Blending qualitative and quantitative research methods in theses and dissertations. CorwinPress.

Todd, T., \& Reid, G. (2006). Increasing physical activity in individuals with autism. Focus Autism Other Develeopmental Disabilities, 21(3), 167-176. https://doi.org/10.1177/10883576060210030501

Verhoef, M. J., \& Love, E. J. (1994). Women and exercise participation: The mixed blessings of mother hood. Health Care Women International, 15(4), 297-306. https://doi.org/10.1080/07399339409516122

Ward-Horney, J., \& Sturmey, P. (2008). The effects of general-case training and behavioral skills training on the generalization of parents' use of discrete-trial teaching, child correct responses, and child maladaptive behavior. Behavioral Interventions, 23(4), 271-284. https://doi.org/10.1002/bin.268 
Yarımkaya, E., İlhan, E. L., \& Karasu, N. (2017). Akran aracılı uyarlanmış fiziksel aktivitelere katılan otizm spektrum bozukluğu olan bir bireyin iletişim becerilerindeki değişimlerin incelenmesi [An investigation of the changes in the communication skills of an individual with autism spectrum disorder participating in peer-mediated adapted physical activities]. Ankara Üniversitesi Eğitim Bilimleri Fakültesi Özel Ĕgitim Dergisi, 18(2), 225-252. https://doi.org/10.21565/ozelegitimdergisi.319423

Yirmiya, N., \& Shaked, M. (2005). Psychiatric disorders in parents of children with autism: A meta-analysis. Journal of Child Psychology and Psychiatry, 46(1), 69-83. https://doi.org/10.1111/j.14697610.2004.00334.X 


\section{Ankara University Faculty of Educational Sciences Journal of Special Education}

2021, 22(2), 343-367

\title{
The Effect of Adapted Physical Activities Implemented by Mothers having Children with Autism Spectrum Disorder on the Mothers' Quality of Life
}

\author{
Oğuz Kaan Esentürk 1
}

Erkan Yarımkaya (iD)

\begin{abstract}
Introduction: In this research, it was aimed to examine the effects of adapted physical activity (APA) program applied by mothers having children with Autism Spectrum Disorder (ASD) on the mothers' quality of life.
\end{abstract}

Method: 24 mothers having children with ASD participated in the research, which was designed in the mixed model (implementation group $=12$, control group $=12$ ). The APA program was conducted for 12 weeks with the mothers in the implementation group and their children with ASD. Before the APA program, family training sessions were held for three days in order for mothers to gain the ability to apply the activities in the program. The quantitative data of the study were obtained through the Beach Center Family Quality of Life Scale, and the qualitative data were obtained using a semi-structured interview form.

Findings: The findings showed that there was a positive significant difference in the mothers' quality of life before and after the APA program. In the follow-up test obtained three weeks after the research, it was determined that the positive change observed in the mothers' quality of life after the APA program continued.

Discussion: As a result, it has been revealed that the APA program applied by mothers has a positive effect on the mothers' quality of life participating in the research.

Keywords: Parental involvement, mother, quality of life, autism spectrum disorder, adapted physical activity.

To cite: Esentürk, O. K., \& Yarımkaya, E. (2021). The effect of adapted physical activities implemented by mothers having children with autism spectrum disorder on mothers' quality of life. Ankara University Faculty of Educational Sciences Journal of Special Education, 22(2), 343-367. https://doi.org/10.21565/ozelegitimdergisi.686849

\footnotetext{
${ }^{1}$ Assist. Prof. Dr., Erzincan Binali Yıldırım University, esenturk954@gmail.com, https://orcid.org/0000-0002-0566-838X ${ }^{2}$ Corresponding Author: Dr., Ministry of National Education, yarimkayaerkan@ gmail.com https://orcid.org/0000-0003-4337$\underline{5112}$
} 


\section{Introduction}

ASD is a neuro-developmental disorder which is characterized by inadequate social interaction and communication skills along with repetitive behaviors (American Psychiatric Association, 2013). The stress in the lives of families with children with ASD cause anxiety, depression and familial problems between spouses. These problems are likely to occur in the life of a family with a child with special needs. This causes even more concern in the lives of families with children with ASD (Hastings \& Brown, 2002). A meta-analysis study revealed that the parents of children with ASD exhibited more psychiatric disorders than parents of typically-developing children (Yirmiya \& Shaked, 2005). In addition, these families experienced more stress (Ingersoll \& Hambrick, 2011; Schieve et al., 2007). They were exposed to more problems in physical activity and social relationships (Mugno et al., 2007; Yirmiya \& Shaked, 2005).

The difficulties experienced by families with children with ASD negatively affect their quality of life. ASD can have a negative effect not only on the quality of life of the person who has this diagnosis, but also on the quality of life of his or her family, as seen in chronic diseases (Farnik et al., 2010; Meltzer, 2001). The low quality of life of families with children with ASD is likely to be affected by various factors such as socio-economic status, social support, parent-child characteristics, and coping strategies (Lee et al., 2009; Mugno et al., 2007). However, having children with ASD has the potential to affect the general competencies and quality of life of other family members (Schalock, 2000; Shu \& Lung, 2005).

The quality of life is a multi-dimensional concept that covers relational, psychological and physical aspects which are broader than health and well-being (Lee et al., 2009). Regarding family life, this concept can be defined as being able to meet the needs of the family, to spend time on what the family members consider as important, and to be happy as a family (Hoffman et al., 2006). Therefore, it is extremely important to carry out interventions that will increase the quality of life of families with children with ASD. The National Autism Center (NAC) and The National Professional Development Center on Autism Spectrum Disorder (NPDC on ASD) recommended a number of evidence-based activities and intervention programs in terms of the development of children with ASD. One of the implementations suggested by these organizations is adapted physical activity (APA). APA is among the promising interventions as revealed by the reports of NAC (2015) and NPDC on ASD (2014). Exercise-based practices have positive effects on the affective features (Bass et al., 2009), motor skills (Pan, 2010), cognitive development (Nicholson, Kehle, Bray, \& Van Heest, 2011), stereotypical behaviors (Prupas $\&$ Reid, 2001) and language development of individuals with ASD (Yarımkaya et al., 2017). The interventions proposed by NAC and NPDC on ASD may also have positive effects on the social life of the parents. Therefore, these programs can be used to increase the quality of life of the parents (Baghdadli et al., 2014). However, previous studies examining family involvement, ASD and APA program generally focus on the deficiencies in the developmental areas of children with ASD (Esentürk, 2019; Solomon et al., 2014). In these studies, after the APA program was implemented by the parents, the changes in the social interaction and communication skills of children with ASD were addressed. But the parameters such as stress, anxiety and especially quality of life that belonged to family members were not measured. Therefore, considering the negative effects of ASD on family's quality of life, the changes in the quality of life of the parents who participate in the APA program need to be examined. The aim of the present research is to examine whether the APA program implemented by mothers has an effect on the quality of life of mothers having children with ASD. In line with this purpose, there research questions were sought in the following:

1. Is there a significant difference between the pre- and post-test scores of the mothers in the implementation and control groups in terms of quality of life?

2. Is there a significant difference between the pre-test, post-test and follow-up test scores in terms of the quality of life of the mothers in the implementation group in terms of quality of life?

3. What were the opinions of the mothers in the implementation group regarding the effect of the APA program on the quality of life?

\section{Method}

This study examined the effect of APA program on mothers' quality of life. A mixed method design was utilized, which included quantitative and qualitative methods. Creswell (2005) describes this design as a research approach in which quantitative and qualitative data are collected and analyzed simultaneously or sequentially. The findings are evaluated as a whole. In this study, sequential exploratory pattern was preferred as it allowed the justification of the qualitative data. 
A total of 24 mothers with children diagnosed with ASD according to DSM-5 were included in the study on a voluntary basis. 12 of the mothers were in the implementation group and 12 were in the control group. In the process of identifying both groups, Beach Center Family Quality of Life Scale that was adapted to Turkish by Meral and Cavkaytar (2013) was implemented. The aim was to form groups that were equivalent to each other in terms of the dependent variable.

The independent variable was the APA program performed by mothers. In the process of preparing the theoretical framework of the APA program, the Developmental, Individual Difference, Relationship-based (DIR) model of Greenspan and colleagues was used (Greenspan, 1992). Also, the relevant literature examining the skills that involved in the activities to maximize the interaction between mother and child and the quality of the time they spent included the win-lose dilemmas and encouraged children to communicate verbally and non-verbally (Fragala-Pinkham et al., 2005; Garcia-Villamisar \& Dattilo, 2010; Gutman et al., 2012; Kunzi, 2015; Menear \& Neumeier, 2015; Srinivasan et al., 2014; Staples et al., 2011; Todd \& Reid, 2006). The general content of the program includes warm-up movements, functional exercises, educational games, sports competitions and stretching-cooling sections. The APA program consisted of two parts: The preparations before the implementation and the steps to be followed during theimplementation process. The aim was to instruct the mothers to implement the APA program to their children with ASD through family trainings.

Family trainings were organized for mothers to help them become competent in implementing the program. Previous studies on family education showed that education programs for families were carried out through informative presentations, modeling, role play and feedback (Lequia et al., 2013; Mazurik-Charles \& Stefanou, 2010). Training activities for mothers were carried out before the implementation process started. Family trainings were held in a classroom with in the workplace of the first author. The classroom had an appropriate eating arrangement with which the mothers felt comfortable. Additional arrangements included the equipment required for presentations, the whiteboard and adjustable heat and light arrangement. In the family education, each mother was given a handbook with the necessary theoretical information to perform the activities. The implementation parts of the family trainings and the activities within the scope of the program were carried out in the gym located within the workplace of the first author. The gym was approximately $200 \mathrm{~m}^{2}$. It had a rubber floor and its walls were covered with soft cushions. There was an area that would allowre wards and materials to be kept in the way that the child could not see.

In this study, both quantitative and qualitative data were collected. Quantitative data of the research were conducted through the Beach Center Family Quality of Life Scale adapted to Turkish by Meral and Cavkaytar (2013). Qualitative data were gathered through the Semi-Structured Interview Form. In the analysis of the quantitative data, the SPSS was used. During the analysis, the distribution of the data was normal. Descriptive statistics were calculated in the study (frequency, percentage, mean, standard deviation). T-test was utilized to identify whether independent differences were significant for the quality of life as pre-test results of the implementation and control groups were considered. Inaddition, ANOVA for repeated measurements test was used to investigate the effect of APA program. In the analysis of the qualitative data, thematic analysis was used. According to Liamputtong (2009), thematic analysis is the process of establishing a thematic framework for analysis and defining the data in the light of this framework, investigating the cause-effect relationship between the findings, and interpreting the relationships observed by the researcher. Thematic analysis can be applied in two ways: Induction and deduction. Inductive thematic analysis method was used in this research. In this analysis, the data are coded regardless of the researcher's bias or a pre-existing code scheme, since defined themes and categories have a strong relationship with the data (Thomas \& Murray, 2003). The process begins within the framework of defined or possible themes. However, the analysis process that starts with the existing themes continues with the creation of new themes (Merriam, 2015).

\section{Results and Discussion}

With the increasing interest in the quality of life of individuals with special needs, previous studies have recently started to focus on the quality of life in individuals with ASD. This study investigated whether the APA program implemented by mothers having children with ASD had an effect on the quality of life of the mothers. In line with this purpose, the mothers were given the ability to apply the APA program before and after the implementation, the changes in the quality of life of the mothers were identified. Qualitative findings were also presented to analyze these changes in the quality of life in depth.

There were positive changes in the quality of life of the mothers following the program. These changes continued in the follow-up (three weeks after). The participants expressed positive opinions as there were positive 
changes in the quality of life after the program. These opinions were related to family support and support for disability through the program, positive interactions with the children in the program, the feeling of being able to do something for their children and learning interactive activities that they were able to perform with their children inside or outside the home. These findings regarding the quality of life of the mothers included some possible reasons. As mothers witnessed the positive changes in the developmental areas of their children with ASD during the program, this had a positive effect on their quality of life. Previous studies showed that participation in the APA program had positively changed many areas of development such as social interaction and communication skills, behavioral problems, repetitive behaviors and cognitive skills of children with ASD (Alexander et al., 2011; Bahrami et al., 2012; Bass et al., 2009; Brookman et al., 2003; Chu \& Pan, 2012; Gabriels et al., 2012; Hameury et al., 2010; Movahedi et al., 2013; Nicholson et al., 2011; Pan, 2010; Pitetti et al., 2007; Prupas \& Reid, 2001; Yarımkaya et al., 2017). The effects of the APA program on children with ASD were also observed as they participated in the current study.

Having a child with ASD also means that parents' physical and mental functions are affected as well as increased stress, sleep deprivation and fatigue (Giallo et al., 2013; Seymour et al., 2013). Community prejudices, increased care responsibilities, and high financial demands in the education process of children with ASD can reduce families' opportunities to socialize and hinder their capacity to make positive changes in their environment (Gray, 2008; McCann et al., 2012; Sawyer et al., 2010; Sharpe \& Baker, 2007). All these negative points cause a decrease in the quality of life compared to families who have typically-developing children (Beadle-Brown et al., 2009; Yirmiya \& Shaked, 2005). In addition to witnessing the development of children with ASD, family participation in programs such as APA can support family members in overcoming the problems (Currie, 2018; Verhoef \& Love, 1994). Another possible reason for the positive results regarding the quality of life of the mothers is the ability of mothers to implement the APA program. A family education program was organized for the mothers to help them become competent in implementing the program for their children with ASD. The preparations before the implementation of program and the steps to be followed during the implementation were shown to the mothers. The mothers were able to perform the exercises in the program with their children in daily life, as well. During the interviews with the mothers, they reported that they easily performed the exercises in daily life with their children, which positively contributed to their quality of life.

Previous studies provided parents with the various educational skills for their children with ASD (Bergan et al., 1983; Charlop-Christy \& Carpenter, 2000; Ward-Horney \& Sturmey, 2008). However, there is a limited number of studies that provide families with the ability to utilize APA program (Esentürk, 2019; Solomon et al., 2014). Unlike Esentürk (2019) and Solomon et al. (2014), the focus of this study was not on the developmental areas of children with ASD, but on the quality of life of the mothers. In this respect, it is thought that current findings will contribute to the literature.

Consequently, the APA program had a positive effect on the quality of life of the mothers. In spite of these meaningful and positive results achieved within the scope of the research, there were some limitations. The study was carried out on 24 mothers who had children with ASD, half of them were in the implementation and the remaining half were in the control group. The following suggestions can be made for future studies:

1. Although mothers were subjected to a theoretical and applied family training program for three days in order to gain the competence to offer APA program before the research, it was observed that mothers experienced confusion in the preparation, presentation and finishing parts of the activities on some days. In the following days, this problem was solved by making pre-activity preparatory talks with the mothers. In future studies, by paying attention to this situation, starting from the first study, preparatory interviews can be made with the mothers before the activity.

2. The family education book given to families contributed greatly to the mothers to be able to apply the APA program in the study. Mothers also benefited from the family education handbook as well as the APA program implementation skills training and successfully implemented the APA program for their children. In this context, materials such as family education handbook used in the current study or in a different study can be transformed into web-based applications and made available to families.

3. Various informative studies can be conducted to parents who have children with ASD about the effects of the APA program on their children and their own development, and awareness can be created that families with children with ASD can easily offer the APA program to their children. 
4. The APA program was applied for 40 minutes three days a week for 12 weeks. The APA program can be applied by increasing the total duration and number of sessions in future studies.

5. In the research, some examples of physical activity such as warm-up activities, educational games, station tracks, sports competitions, functional movements and stretching-cooling exercises were shown to mothers to provide the APA program to their children with ASD. A handbook containing adaptation of different physical activities for children with ASD can be created for the benefit of parents. Considering the time spent by the mothers of children with ASD in the home environment and the pandemic process, examples of home-based physical activities and games that can be done at home can be included in the handbook.

\section{Author's Contributions}

The authors of the study worked together in determining the subject of the study, research design, data collection, data analysis and reporting of the study.

\section{Acknowledgment}

We would like to thank our precious mothers and special children for their participation in the research, who willingly participated in each physical activity study throughout the research. 